ISSN 1330-9862

review

doi: $10.17113 / \mathrm{ftb} \cdot 54.04 .16 .4248$

\title{
Biochemistry of Apple Aroma: A Review
}

\author{
Miguel Espino-Díaz', David Roberto Sepúlveda ${ }^{1}$, Gustavo González-Aguilar ${ }^{2}$ \\ and Guadalupe I. Olivas ${ }^{1 *}$
}

${ }^{1}$ Research Center for Food and Development (CIAD), Rio Conchos S/N, MX-31570 Cuauhtémoc, Mexico

${ }^{2}$ Research Center for Food and Development (CIAD), Carretera a la Victoria km. 0.6, MX-83000 Hermosillo, Mexico

Received: May 7, 2015

Accepted: May 16, 2016

\begin{abstract}
Summary
Flavour is a key quality attribute of apples defined by volatile aroma compounds. Biosynthesis of aroma compounds involves metabolic pathways in which the main precursors are fatty and amino acids, and the main products are aldehydes, alcohols and esters. Some enzymes are crucial in the production of volatile compounds, such as lipoxygenase, alcohol dehydrogenase, and alcohol acyltransferase. Composition and concentration of volatiles in apples may be altered by pre- and postharvest factors that cause a decline in apple flavour. Addition of biosynthetic precursors of volatile compounds may be a strategy to promote aroma production in apples. The present manuscript compiles information regarding the biosynthesis of volatile aroma compounds, including metabolic pathways, enzymes and substrates involved, factors that may affect their production and also includes a wide number of studies focused on the addition of biosynthetic precursors in their production.
\end{abstract}

Key words: apple aroma, volatile compounds, precursor, lipoxygenase (LOX), alcohol dehydrogenase $(\mathrm{ADH})$, alcohol acyltransferase (AAT), pathway

\section{Introduction}

Apple quality is determined by attributes such as appearance, firmness and flavour, as well as by the absence of physiological and pathological disorders. However, the concept of quality in fruits has evolved, and increasing attention is currently given to sensory attributes to achieve higher acceptance by consumers (1). Flavour is one the most important and distinctive features of apples, and it is determined by both taste and aroma $(2,3)$. While taste is mainly determined by sugars and organic acids, aroma is a complex mixture of many volatile compounds whose composition is specific to the species and often to the variety $(3-5)$. The volatile aroma compounds in apple have been studied for more than 50 years. In this period, more than 300 compounds have been identified (6-8), with only a few that contribute significantly to the fruit aroma. They mostly include esters, alcohols, aldehydes, ketones and ethers (6). Aldehydes predominate in immature apples $(8-10)$, but their content decreases as the fruit matures, a period in which the concentration of alcohols and esters increases, the latter being the main volatile compounds in ripe apples $(11,12)$. All the volatile compounds are of great importance for the complete characteristic aroma profile of apples (8). Their composition and concentration differ among varieties $(4,13,14)$, and their production can also be affected by several factors before, during and after the harvest.

This manuscript describes the main volatile compounds of apple aroma, their biosynthesis, and the main factors affecting their production. Finally, studies on the application of external precursors in the production of volatile compounds in apple are discussed. 


\section{Volatile Aroma Compounds in Apple}

In apples, the profile of volatile compounds changes with maturation; aldehydes predominate at the beginning, then the content of alcohols starts to increase considerably, and finally the profile is dominated by esters (15). Therefore, it is important to discuss exactly how the cultivar and biotic and abiotic factors affect the profile of aldehydes, alcohols and esters in apples.

Aldehydes derive mainly from the catabolism of fatty acids $(9,16)$. They can also derive from branched-chain amino acids such as isoleucine, leucine and valine $(17,18)$. There are reports of more than 25 aldehydes in apple (6), mostly hexanal, trans-2-hexenal and butanal. Aldehydes are abundant in pre-climacteric apples (19), but after ripening, the content of some aldehydes becomes almost imperceptible $(9,20)$. However, when volatile content is determined in homogenized tissue (juice), high concentrations of some aldehydes are found, mostly hexanal and hexenals $(21,22)$. Under hypoxic conditions apples can also produce acetaldehyde (23), which can be reduced to ethanol. Nonetheless, there are apple varieties such as Royal Gala $(22)$ and Golden Delicious $(23,24)$ that are very resistant to extremely low oxygen concentrations (Table 1 ; $6,10,19,21,22,25-27)$.

Alcohols are formed by the reduction of corresponding aldehydes, by the action of the enzyme alcohol dehydrogenase (ADH) (28-30). Linear alcohols are derived from the fatty acid catabolism, whereas branched-chain alcohols are produced by the metabolism of branched amino acids $(31,32)$. Alcohols are the second most important compounds that contribute to the aroma of ripe apples after esters (33), the most abundant being 2-methyl-1-butanol, 1-butanol, 1-hexanol, 1-propanol and 2-methyl-1-propanol (14,34-36). They are direct precursors of esters (6), which may occasionally be fragmented to their corresponding alcohols and fatty acids by the action of esterases $(37-41)$. It has been reported that apples synthesize more than 40 alcohols in apples (6).
In the last step of volatile compound synthesis, the alcohol acyltransferase (AAT) enzyme transfers an acyl group from acyl-CoA to the $\mathrm{OH}$ group of an alcohol to form an ester (42). This occurs in both fatty acid and amino acid catabolism $(15,43,44)$. In ripe apples, alcohols constitute 6 to $16 \%$ of the total volatiles (8), whereas esters represent, depending on the apple variety, from $80 \%$ in Golden Delicious and Golden Reinders $(14,45)$ to $98 \%$ in Starking Delicious (36). Esters can have linear or branched chains, and their concentration depends on the availability of precursors $(37,46,47)$ and on the selectivity and activity of the enzymes involved (48-51). Butyl acetate, hexyl acetate, 2-methylbutyl acetate and ethyl 2-methyl-butanoate are the most important esters due to their high content and impact on apple aroma of several varieties $(6,52)$. Table $2(6,12,14,25-27,45,48,53-62)$ shows the main alcohols and esters in apples found in different apple varieties at the moment of harvest.

\section{Biosynthesis of Volatile Compounds in Apples}

Volatile compounds are synthesized from fatty acid metabolism, amino acid metabolism, and carbohydrate metabolism $(5,63,64)$, through the following pathways $(40)$ : (i) straight-chain aldehydes, alcohols and esters are synthesized from lipids, mainly linolenic and linoleic acids, through $\beta$-oxidation and lipoxygenase activity $(8,16)$, (ii) branched-chain aldehydes, alcohols and esters are derived from isoleucine $(17,65-67)$, (iii) terpenoids are synthesized via the mevalonate pathway $(63,68)$ and deoxyxylulose phosphate pathway (69), and (iv) phenylpropanoids are synthesized from the phenylpropanoid pathway (70).

Fatty acids with 16 and 18 carbons are the most predominant in apples (C16:0, C18:0, C18:1, C18:2 and C18:3) (71), which are the principal substrates for the production of volatiles (72). The lipid content and concentration of fatty acids in pre- and postharvest climacteric apples are similar, reaching their maximum concentration in the climacteric period (71-75). The most important amino acids for the biosynthesis of volatile compounds in apples are

Table 1. Proportion of aldehydes in the total volatiles identified in each apple variety

\begin{tabular}{|c|c|c|c|c|c|c|c|c|c|}
\hline \multirow{3}{*}{$\begin{array}{l}\text { Volatile } \\
\text { compound }\end{array}$} & \multirow{3}{*}{ Descriptive odour } & \multicolumn{2}{|c|}{ Fruit } & \multicolumn{5}{|c|}{ Juice } & \multirow{2}{*}{$\begin{array}{c}\text { Fruit } \\
\text { GRE } \\
(22)\end{array}$} \\
\hline & & $\begin{array}{l}\text { GD } \\
(19)\end{array}$ & $\begin{array}{l}\text { BD } \\
(10)\end{array}$ & $\begin{array}{c}\text { FJ } \\
(21)\end{array}$ & $\begin{array}{l}\text { GRU } \\
(21)\end{array}$ & $\begin{array}{l}\text { GD } \\
(21)\end{array}$ & $\begin{array}{l}\text { GS } \\
(21)\end{array}$ & $\begin{array}{c}\text { PL } \\
(21)\end{array}$ & \\
\hline & & \multicolumn{2}{|c|}{ Before maturation } & \multicolumn{5}{|c|}{ At harvesting } & $\begin{array}{l}\text { After } \\
\text { ULO }\end{array}$ \\
\hline Acetaldehyde & pungent, ethereal (6), fruity (25) & & & & & & & & 1.13 \\
\hline Propanal & penetrating $(6,25)$ roasted coffee $(6)$ & & 0.60 & & & & & & \\
\hline Butanal & pungent $(6,25)$, diluted fruity $(6)$ & & 3.19 & 0.10 & 0.19 & 0.08 & 0.18 & 0.13 & 0.08 \\
\hline Hexanal & green grassy (25), green apple (26) & 3.66 & 12.2 & 0.34 & 0.25 & 0.32 & 3.08 & 0.34 & 34.37 \\
\hline trans-2-hexenal & green fruit (6), pungent vegetable (6) & 1.55 & 0.31 & 0.66 & 0.39 & 0.42 & 6.79 & 1.00 & 37.56 \\
\hline Heptanal & pungent, greasy (25) & 2.98 & 14.9 & & & & & & \\
\hline Octanal & citric fruit (27), strong (25) & 5.76 & 13.24 & & & & & & \\
\hline Nonanal & orange-rose, waxy (25) & 34.54 & 26.04 & & & & & & \\
\hline Decanal & orange skin, citric (25) & 0.38 & 7.86 & 0.09 & 0.10 & 0.08 & 0.21 & 0.19 & \\
\hline Benzaldehyde & almond oil (25) & 2.49 & 0.60 & 0.16 & 0.03 & 0.01 & 0.08 & 0.02 & 0.03 \\
\hline
\end{tabular}

GD=Golden Delicious, BD=Bisbee Spur Delicious, FJ=Fuji, GRU=Gold Rush, GS=Granny Smith, PL=Pink Lady, GRE=Golden Reinders; $\mathrm{ULO}=$ ultra-low oxygen 


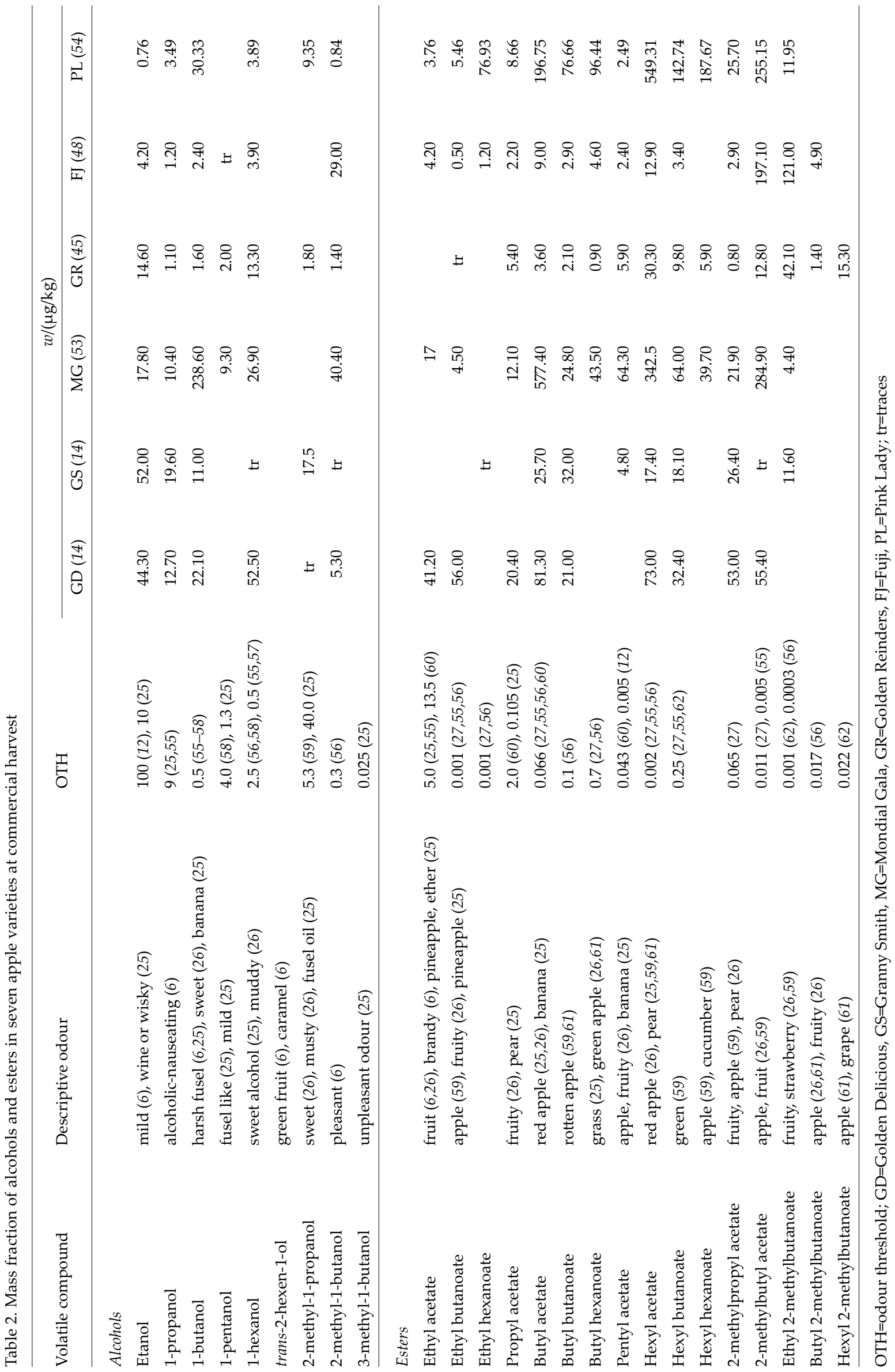


those with branched chains (leucine, isoleucine and valine), although in other fruits, phenylalanine, tyrosine and tryptophan are important as well $(76,77)$. The concentration of most amino acids decreases with the maturation of apples (78-81) due to the synthesis and metabolism of proteins (78). During storage, an initial reduction in the content of amino acids occurs, without significant change afterwards (78). On the other hand, there are two main groups of flavour compounds that come directly from carbohydrate metabolism: terpenoids and furanones (3). The following section describes the main pathways involved in the biosynthesis of volatile compounds in apples from fatty acids, amino acids and carbohydrates.

\section{Fatty acid metabolism}

In apples, $\beta$-oxidation and the lipoxygenase (LOX) pathway are the two main enzymatic systems in the catabolism of fatty acids for the formation of aldehydes, alcohols and esters $(32,34,44,82)$, the former being more important in intact fruit $(16,83)$ and the latter in cut fruit $(5,84)$. Nonetheless, as apples mature, the rates of both lipid synthesis and degradation increase, causing a change in membrane fluidity, thereby increasing its permeability to different substrates $(71,83)$. This, along with the breakdown of chloroplasts, which release fatty acids such as linoleic (C18:2) and linolenic (C18:3) acids (71), make the LOX pathway an alternative to $\beta$-oxidation of the whole fruit, which is confirmed by high activity of the LOX pathway enzymes during apple development $(34,54,73,85)$.

\section{$\beta$-Oxidation of fatty acids}

$\beta$-Oxidation is the main pathway involved in the degradation of fatty acids, and in plants it is mainly performed in peroxisomes (86-88), which contain all the necessary enzymes. During $\beta$-oxidation, fatty acids are activated to their corresponding acyl coenzyme A (CoA) by acyl-CoA synthase in a reaction requiring adenosine triphosphate (ATP), $\mathrm{Mg}^{2+}$ and coenzyme A with sulfhydryl functional group (CoASH) $(89,90)$. The acyl-CoA is then imported into the peroxisome.

The main cycle of $\beta$-oxidation, known as the core $\beta$-oxidation cycle, includes four enzymatic reactions (87) performed by three proteins: (i) acyl-CoA oxidase, (ii) a multifunctional protein containing domains responsible for four enzymatic activities (2-trans-enoyl-CoA hydratase, L-3-hydroxyacyl-CoA dehydrogenase, D-3-hydroxyacyl-CoA epimerase and $\Delta^{3}, \Delta^{2}$-enoyl-CoA isomerase), and (iii) L-3-ketoacyl-CoA thiolase $(89,90)$. In the first reaction of the main cycle of $\beta$-oxidation, acyl-CoA is transformed into trans-2-enoyl-CoA by acyl-CoA oxidase. This reaction requires flavin adenine dinucleotide (FAD) as a cofactor and $\mathrm{O}_{2}$ as an electron acceptor. The $\mathrm{O}_{2}$ is reduced to $\mathrm{H}_{2} \mathrm{O}_{2}$, which is degraded by catalase inside the peroxisome (90). In the second reaction, 2-trans-enoyl-CoA hydratase catalyzes the hydration of trans-2-enoyl-CoA to 3-hydroxyacyl-CoA, which is oxidized to 3-ketoacyl-CoA by L-3-hydroxyacyl-CoA dehydrogenase in the third reaction of the cycle, requiring $\mathrm{NAD}^{+}$as a cofactor. In the fourth reaction of the $\beta$-oxidation cycle, 3-ketoacyl-CoA thiolase catalyzes the breakage of the thiol end of 3-ketoacyl-CoA resulting in one molecule of acetyl-CoA and one of acyl-CoA after the removal of two carbons, which return to the $\beta$-oxidation cycle. This cycle is repeated with the oxidative removal of two carbon atoms in the form of acetyl-CoA from the carboxyl end of a fatty acid until it is completely oxidized (Fig. 1; 86,87,89-91). The final product of the $\beta$-oxidation of fatty acids with odd number of carbon atoms is an acyl-CoA in which the fatty acid has five carbon atoms. The products of oxidation and breakdown are acetyl-CoA and propionyl-CoA (91).
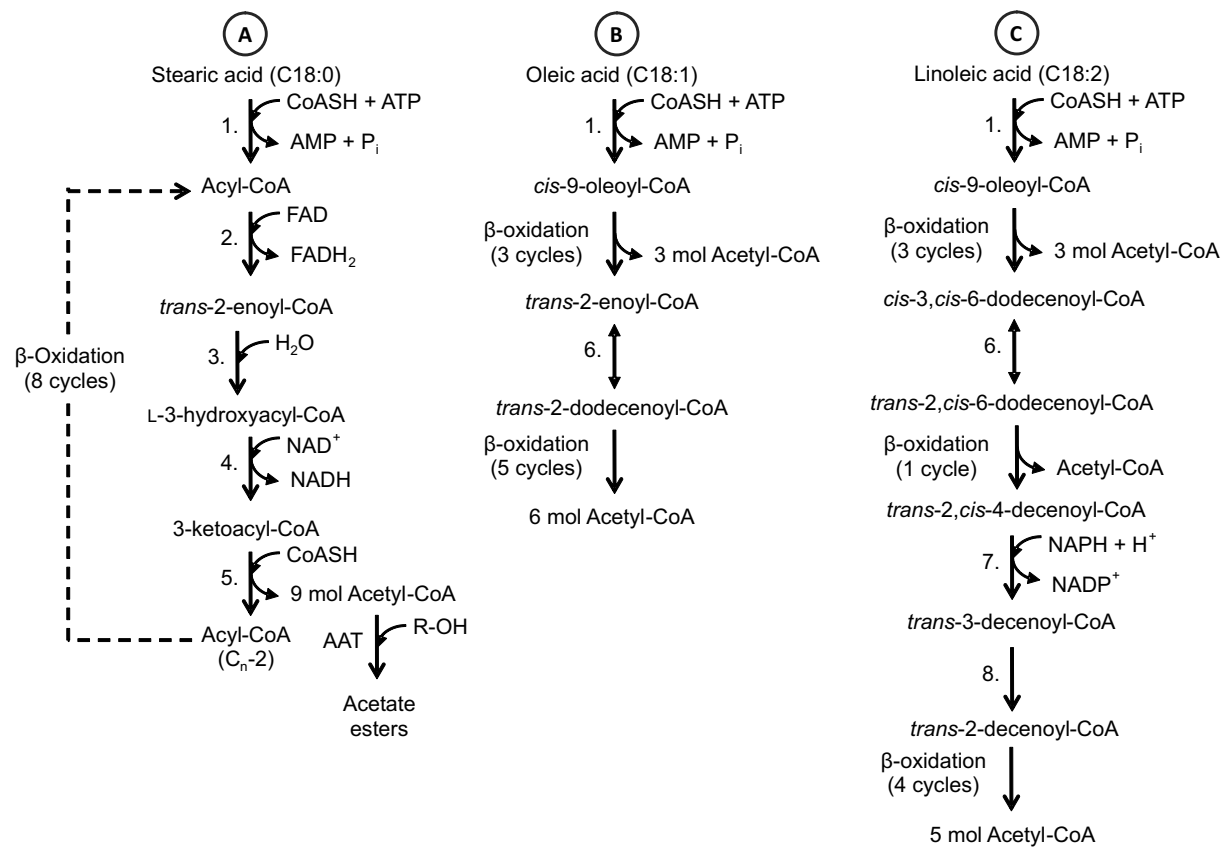

Fig 1. $\beta$-Oxidation pathway of $\mathrm{C} 18$ fatty acids. $\mathrm{A}=$ saturated fatty acid (stearic), $\mathrm{B}=$ unsaturated fatty acid with one double bond in cis configuration (oleic), $\mathrm{C}=$ unsaturated fatty acid with two double bonds in cis configuration (linoleic). Adaptations based on $86,87,89$ 91. 1. acyl-CoA synthetase, 2. acyl-CoA oxidase, 3. trans-2-enoyl-CoA hydratase, 4. L-3-hydroxyacyl-CoA dehydrogenase, 5. 3-ketothiolase, $6 . \Delta^{3}, \Delta^{2}$-enoyl-CoA isomerase, 7. 2,4-dienoyl-CoA reductase, 8 . enoyl-CoA isomerase 
The enzymes of the main $\beta$-oxidation cycle are able to catabolize linear saturated fatty acids or those with double trans bonds in the $\Delta^{2}$ position $(86,89,90)$. Some linear fatty acids with double cis bonds have odd number of carbon atoms and they form enoyl-CoA molecules that cannot be metabolized by the enzymes of the main $\beta$-oxidation cycle. Three auxiliary enzymes have been identified: (i) a $\Delta^{3} \Delta^{2}$-enoyl-CoA isomerase that converts 3-cis- or 3-trans-enoyl-CoA to 2-trans-enoyl-CoA, which can be incorporated into the main $\beta$-oxidation cycle (90), (ii) a 2,4-dienoyl-CoA reductase that catalyzes the conversion of 2-trans,4-cis-dienoyl or 2-trans,4-trans-dienoyl-CoA into 3-trans-enoyl-CoA, and (iii) a $\Delta^{3,5} \Delta^{2,4}$-dienoyl-CoA isomerase that catalyzes the conversion of 3,5-dienoyl-CoA to 2,4-dienoyl-CoA $(86,87)$. All these enzymes are required for the conversion of fatty acids in plants (90). Linoleic and linolenic acids have double bonds with a cis configuration and an even number of carbon atoms. Fig. 1 shows the enzymes, cofactors and products involved in the degradation of stearic, oleic and linoleic acids, all present in apples, through the $\beta$-oxidation pathway $(86,87,89-91)$. The $\beta$-oxidation of long-chain fatty acids produces shorter acids such as acetic, butanoic and hexanoic acids, which can be reduced to their corresponding alcohols (16) before being esterified with acyl-CoA by the alcohol acyltransferase (AAT) enzyme. The combination of acyl-CoA molecules with different alcohols results in an important range of esters. However, given that acetyl-CoA is the main acyl-CoA produced in $\beta$-oxidation, most of the esters are acetate esters (23).

\section{Lipoxygenase pathway}

Lipoxygenase (LOX; EC 1.13.11.12) is a dioxygenase that catalyzes the oxygenation of polyunsaturated fatty acids containing a cis-1,4-pentadiene fraction, and the product is a conjugated diene (cis, trans) hydroperoxide (HPO) (92,93). Linoleic and linolenic acids are the main substrates of $\operatorname{LOX}(3,94)$, which are released from triacylglycerols, phospholipids and glycolipids by the action of acyl hydrolases (32).

Plant LOXs are classified on the basis of their primary structure and putative subcellular localization into two gene subfamilies: type 1, localized within cytosol, and type 2, which are chloroplastic proteins (95-97). LOX enzymes are also classified according to the carbon targeted for deoxygenation in the polyunsaturated fatty acid, which can be carbon 9 (9-LOX) or 13 (13-LOX) $(94,95,98$, 99). Most type 1-LOXs produce 9-hydroperoxide, and type 2-LOXs produce almost exclusively 13-hydroperoxide derivatives from polyunsaturated fatty acids (97). However, some LOX enzymes have dual positional specificity (95, 100-102).

In Royal Gala apples, 11 LOX genes have been identified (40). Li et al. (103) identified 36 genes homologous to LOX in the apple (Malus domestica) genome, using the domain of 'Lipoxygenase' from Pfam database (104). Vogt et al. (96) identified 23 putative LOX genes in the genome of Golden Delicious apple reported by Velasco et al. (105). Based on sequence similarity, the 23 LOX genes were assigned to seven clusters. Clusters with their putative functional sequences were: LOX1a-e, LOX2a and $-b, L O X 3 a$ and $-b$, LOX5a-e, LOX6 $a$ and $-b, L O X 7 a-d$, and LOX8a and -b. Only LOX9 represents a single gene (LOX9a) (96). Vogt et al. (96) also predicted the subcellular location of LOX genes. Genes of LOX1, -3 and -7 clusters encode cytoplasmic 1-LOX proteins, which may be 9-LOX, whereas LOX2, $-5,-6$ and -8 clusters encode chloroplast 2-LOX proteins, which may be 13-LOX, according to Feussner and Wasternack's (95) classification.

Using linoleic or linolenic acid as substrate, enzyme LOX1c produced mainly 9-hydroperoxide (77 \%), whereas LOX2b produced predominantly 13-hydroperoxide (106). However, LOX1a and LOX2a enzymes exhibited a dual positional function producing 13- and 9-hydroperoxides in a ratio of $8: 1$. The latter two enzymes were classified with 13/9-specificity (106).

The genes MdLOX1a and MdLOX5e were found to be involved in the production of volatiles in Alkmene, Discovery, McIntosh, Royal Gala and Prima apples. More recently, four genes (LOX1a and $-c$ and LOX2 $a$ and $-b$ ) were related to Golden Delicious apple aroma (106). The genes $M d L O X 2$ and MdLOX5 were expressed in leaves, flowers and fruits of Golden Delicious and McIntosh, whereas the remaining genes were expressed in a different way or were absent from tissues. LOX genes exclusively expressed in fruits were not found (96). Of the 22 LOXs, 17 were expressed in Jonagold apple peel (107). However, little is known about the specific function of each LOX isoform (96).

Products of the LOX reaction can be converted to different compounds, through at least six pathways (100). One of these pathways is through the hydroperoxide lyase (HPL) enzyme (108) (Fig. 2; 16,29,32,63,109). HPL is an enzyme belonging to the cytochrome P450 CYP74B/C family and acts on hydroperoxides with no need for cofactors (63) to form short-chained aldehydes (6 or 9 carbon atoms) $(16,109)$. Some HPL enzymes break only 9-HPOs (110), others act only on 13-HPOs, and others have dual specificity (111), which can influence the aroma profile of the fruit (5). However, the 9-LOX hydroperoxide derivatives are not totally understood (107). In the apple genome, a total of $39 \mathrm{MdALDH}$ genes were identified (112).

Aldehydes (6 or 9 carbon atoms) are subsequently reduced to the corresponding alcohol by the enzyme alcohol dehydrogenase (ADH) (63). ADH is an oxidoreductase that catalyzes the reversible reduction of aldehydes to alcohols $(68,113,114)$, and its direction is influenced by the $\mathrm{pH}$. However, at physiological $\mathrm{pH}$, the reaction favours the production of alcohols (29). ADH acts on a wide range of linear, branched and cyclic alcohols (29), showing preference for the former in apples $(28,115)$. It also requires the presence of the reduced coenzymes NADH and NADPH, which possess two diastereotopic hydrogens, pro- $R$ and pro-S; the substrate can be attacked from both ends resulting in $(S)$ or $(R)$ alcohols. Most ADH enzymes form $(S)$ alcohols (116).

The alcohols resulting from ADH enzymatic activity are natural substrates for the AAT enzyme, which transfers an acyl group through an oxygen-dependent reaction from acyl-CoA to the OH group of an alcohol (42) forming an ester $(5,33,68)$. The diversity of esters formed by AAT enzymes can be influenced by substrate availability, 


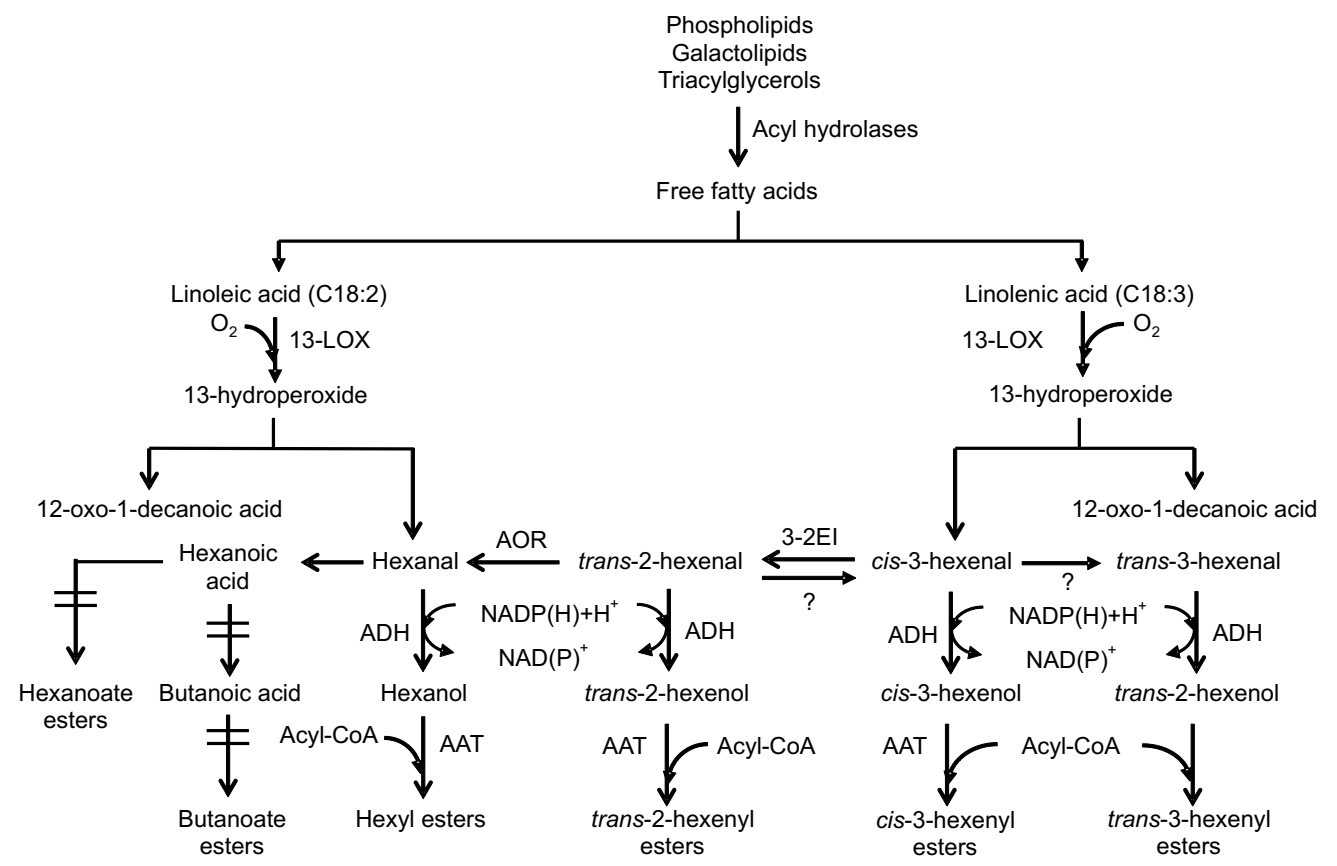

Fig 2. Lipoxygenase pathway in the production of acetate esters from the catabolism of linoleic and linolenic acids. Adaptations based on 16,29,32,63,109. LOX=lipoxygenase, HPL=hydroperoxide lyase, ADH=alcohol dehydrogenase, ALDH=aldehyde dehydrogenase, $\mathrm{AOR}=$ alquenal oxidoreductase, $3-2 \mathrm{EI}=$ cis-3: trans-2-enal isomerase, $\mathrm{AAT}=$ alcohol acyltransferase

the specificity of the enzyme, or by the variety of genes encoding ATT enzymes (49-51). Even though AAT has more affinity for linear than for branched alcohols (17), because acetyl-CoA is the most abundant CoA in fruits, most esters are acetate esters $(33,117)$. There are reports of 15 AAT enzymes in Royal Gala apples (40), although Dunemann et al. (52) identified 17 putative AAT genes in the genome of Golden Delicious apples, while Souleyre et al. (118) reported 18 AAT1 gene models (putative variants) in the Golden Delicious genome. Four variants of AAT1 were identified in Granny Smith (AAT1-GSa-d) and three variants in Royal Gala ( $A A T 1-R G a-c)$; however, only $A A T 1-G S a$ and $A A T 1-R G a$ were expressed and functional in ripe apple fruit, both in skin and cortex tissue (118). Fig. 2 shows the formation of volatile aroma compounds from linoleic and linolenic acids through the LOX pathway, and Table 3 shows some studies that have been per- formed on enzymes from the LOX pathway in different developmental stages of apples $(13,15,34,40,44,45,54,72$, $73,75,79,85,96,106,118-136)$.

\section{Amino acid metabolism}

Amino acids are precursors of volatile aromatic compounds such as aldehydes, alcohols, acids and esters, being the second most important source of volatile compounds in the aroma of fruits and vegetables $(5,32,68)$. In apples, the production of branched-chain esters has been reported from the branched amino acids isoleucine (Ile), leucine (Leu) and valine (Val) $(17,137)$. These amino acids are branched compounds of aliphatic nature and are synthesized in chloroplasts $(138,139)$. Free amino acids in cells originate from proteolysis (140). The branched-chain amino transferase (BCAT) enzyme catalyzes the last step

Table 3. Important enzymes involved in the production of volatile aroma compounds of apple fruit, and their changes at preharvest, harvest and postharvest stages

\begin{tabular}{|c|c|c|}
\hline Cultivar & Enzyme activity & Reference \\
\hline & Lipoxygenase (LOX) & \\
\hline \multicolumn{3}{|l|}{ On the tree } \\
\hline Cox's Orange Pippin & LOX activity increased during ripening & $(73)$ \\
\hline Golden Delicious & LOX activity increased at the end of ripening & $(72)$ \\
\hline Fuji & LOX activity remained constant; twice higher LOX activity in the skin & $(34)$ \\
\hline Starkrimson & LOX activity increased in climacteric stage; subsequent reduction of activity & $(75)$ \\
\hline Jonagold & LOX activity increased until 160 days after full bloom and then remained constant until harvest & $(85)$ \\
\hline Pink Lady & LOX activity increased in climacteric stage; subsequent reduction of activity & $(54)$ \\
\hline Golden Reinders & LOX activity decreased in the skin until harvest; it remained low and unchanged in the pulp & $(119)$ \\
\hline $\begin{array}{l}\text { Golden Delicious } \\
\text { and McIntosh }\end{array}$ & $\begin{array}{l}L O X 2 b,-3 b \text { and }-5 e \text { genes were up-regulated by fruit ripening; } L O X 1 a \text { was detected in the last ripening } \\
\text { stage only in McIntosh }\end{array}$ & $(96)$ \\
\hline
\end{tabular}


Table 3. - continued

\begin{tabular}{lll}
\hline Cultivar & Enzyme activity & Reference \\
\hline Jonagold & LOX-derived C6 aldehydes showed a different pattern among them during fruit ripening & $(120)$ \\
Jonagold & $L O X 6 a,-6 b$ and $-7 c$ gene expression decreased; LOX7a expression showed a slight increase, that of & $(106)$ \\
& $\begin{array}{l}\text { LOX } 4 a \text { sharply increased at the end, and LOX1a expression increased more than 100-fold during } \\
\text { ripening }\end{array}$
\end{tabular}

\section{At harvest}

Greensleeves LOX enzyme remained insensitive to ethylene

Royal Gala LOX1 and -7 genes were regulated by ethylene, but not genes LOX2, -4 and -5

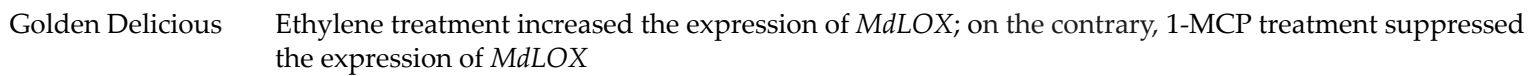

During storage

Schone van Boskoop Higher activity of LOX enzyme in apple core and skin than in the pulp

Fuji

Partial inhibition of LOX enzyme under reduced oxygen conditions

Mondial Gala

3 months under controlled atmosphere or regular atmosphere: inhibition of LOX enzyme under

Fuji controlled atmosphere storage

6 months under controlled atmosphere or regular atmosphere: LOX inhibition under both conditions

7 months under ultra-low oxygen +2 weeks under regular atmosphere: higher activity of LOX and hydroperoxide lyase (HPL) in the skin

7 months under ultra-low oxygen +4 weeks under regular atmosphere: higher activity of LOX and HPL in the pulp

Delbard Estivale Reduction of LOX activity by effect of both 1-MCP and AVG

Golden Reinders

7 months under ultra-low oxygen: partial inhibition of LOX enzyme activity

Golden Delicious Ethephon increased the LOX activity in the apple treated with 1-MCP and stored for 14 weeks under regular atmosphere

\section{Hydroperoxide lyase (HPL)}

\section{On the tree}

Pink Lady

HPL activity increased up to 1 month before harvest

Golden Reinders

HPL activity decreased in apple skin with a slight increase at the beginning of climacteric stage, it

At harvest

Royal Gala

Golden Delicious

HPL enzyme was insensitive to ethylene

Expression of the MdHPL gene was significantly enhanced by ethylene treatment, while 1-MCP

During storage

Pink Lady treatment had no significant effect

Fuji

7 months under low or ultra-low oxygen: higher activity of HPL under ultra-low oxygen storage

5-7 months under ultra-low oxygen: higher activity in the skin after 5 months, and in the pulp after

Golden Reinders

7 months

\section{Alcohol dehydrogenase (ADH)}

On the tree

Fuji

Jonagold

At harvest

Greensleeves

Fuji

Royal Gala

Golden Reinders

Golden Delicious

\section{During storage}

Mondial Gala
$\mathrm{ADH}$ activity decreased with ripening on the tree

ADH activity increased until harvest

Maximum activity at harvest; insensitive to ethylene

Of 10 genes, only $A D H 1$ gene expression was decreased by ethylene

The activity remained stable and increased in the climacteric stage

decreased. 1-MCP treatment increased the expression of $M d A D H 1$, while there was no significant effect on $M d A D H 2$ and $M d A D H 3$

6 months under regular or controlled atmosphere: higher ADH activity under controlled than under regular atmosphere 
Table 3. - continued

\begin{tabular}{lll}
\hline Cultivar & Enzyme activity & Reference \\
\hline Pink Lady & 7 months under ultra-low oxygen: higher activity of ADH in the skin & $(128)$ \\
Delbard Estivale & 1-MCP and AVG under regular atmosphere: reduced activity of ADH & $(126)$ \\
Golden Delicious & $\begin{array}{l}\text { Salicylic acid and methyl jasmonate increased the LOX and ADH activities in apple treated with } \\
\text { 1-MCP and stored for 14 weeks under regular atmosphere }\end{array}$ & $(127)$ \\
\hline
\end{tabular}

\section{Alcohol acyltransferase (AAT)}

On the tree

Fuji and Pink Lady No significant changes in the activity of AAT

Starkrimson Continuous increase in the activity of AAT and subsequent stabilization

Granny Smith Increase of activity with ripening; only expressed in the skin

Fuji Increase of activity with ripening

Golden Reinders

Continuous AAT activity reduction during maturation, and increased with the onset of climacteric

Golden Delicious stage

Fuji

Granny Smith and Royal Gala

At harvest

Greensleeves

Royal Gala

Tsugaru

Golden Delicious

During storage

Law Rome/Red Rome 262

Gala

Greensleeves

Golden Delicious and Granny Smith

Fuji

Golden Delicious

Mondial Gala

Pink Lady

Fuji Kiku 8

Royal Gala

Delbard Estivale

Golden Reinders

Tsugaru

Golden Delicious

McIntosh
MdAAT2 expression increased during apple maturation; it was up-regulated in response to ethephon and methyl jasmonate

In girdled trees with foliar urea, ADH and AAT increased compared to control; in ungirdled trees, AAT activity was not influenced by foliar urea rates

AAT1-GS transcript level increased with apple maturation, peaked at day 120 after full flowering, then decreased slightly; $A A T 1-R G$ transcript level increased during fruit development

The AAT2 gene was regulated by ethylene

The application of 1-MCP reduced the activity of AAT

Increased MpAAT1 isoenzyme activity by ethylene

AAT activity increased with fruit ripening; the 1-MCP reduced the $p M d A A T$ gene expression and the AAT activity

Expression of the MdAAT2 gene was significantly increased by ethylene treatment, while both MdAAT1 and MdAAT2 were strongly reduced in 1-MCP treatment

3 months under controlled atmosphere or 6 months under regular atmosphere: AAT activity was reduced; however, it was recovered after 1 week at room temperature

4 months under controlled or regular atmosphere: inhibition of AAT activity

AAT activity increased $40-60 \%$ from harvest to 20 days of storage at $20^{\circ} \mathrm{C}$

The 1-MCP reduced MdAAT2 expression in Golden Delicious, but not in Granny Smith; MdAAT1 remained constant in Golden Delicious; MdAAT4 and MdAAT3 were suppressed after harvest

3 or 6 months under controlled atmosphere: no significant difference in the AAT activity

Salicylic acid, ethephon and methyl jasmonate increased the
1-MCP and stored for 14 weeks under regular atmosphere

3 months under controlled or regular atmosphere: high activity of AAT

6 months under controlled atmosphere: strong inhibition of the AAT activity

7 months under controlled or regular atmosphere: higher AAT activity under controlled atmosphere

7 months under controlled or regular atmosphere with $2 \% \mathrm{CaCl}_{2}$ : increased AAT activity under regular atmosphere

The combination of AVG and 1-MCP reduced ester production, but treatments did not differ from control in apples stored for 3 months under regular atmosphere

The 1-MCP increased the AAT activity; no effect of AVG

5 months under controlled or regular atmosphere with $2 \% \mathrm{CaCl}_{2}$ : lower AAT activity in apple skin than in pulp activity

MdLOX1a gene was expressed only during storage; MdLOX3b not detected during storage

$M d L O X 7 a$ and $-b$ genes were expressed only during storage; LOX1a, $-2 a$ and $-5 e$ genes continued their

1-MCP=1-methylcyclopropene, AVG=aminoethoxyvinylglycine 
in the synthesis of branched amino acids and the first step of their degradation $(138,139)$. Leu is degraded in plant mitochondria, and Val and Ile might also be degraded in this organelle $(138,139)$ or at least converted into their corresponding ketoacids $(90,139)$ because some of the enzymes required for the catabolism of Leu and Ile are also found in peroxisomes (141). The degradation of branched amino acids helps to maintain the balance between NAD and $\mathrm{NADH}+\mathrm{H}^{+}$. Moreover, the produced acyl-CoA serves as an energy source for ATP production (142).

The catabolism of amino acids has been well documented in bacteria and yeasts $(18,142-144)$. In fruits, it has been demonstrated that the reactions for the derivation of volatile compounds from branched amino acids follow the pathway found in some of these microorganisms. In apples $(17,67,137)$ and fruits such as melon $(31)$, these pathways have been elucidated by the exogenous addition of labelled amino acids. The addition of labelled Leu, Ile, and Val produces a different ester pattern in different apple varieties, which indicates that the isozymes differ in their substrate selectivity (137).

In apple and other fruits, the biosynthesis of volatile compounds from Ile, Leu and Val starts with the removal of the amino group by aminotransferases (BCAT), forming $\alpha$-keto acids (2-oxo-3-methyl pentanoate and 2-oxo-3-methyl butanoate) $(18,90,140,143)$. During this transamination, the amino acids use 2-oxo-ketoglutarate (2-oxoglutarate) as a receptor for the amino group $(18,63,142,145)$, which can be recycled into glutamate by the enzyme glutamate dehydrogenase (GDH) $(18,146)$. $\alpha$-Keto acids can be metabolized by three different pathways $(18,67,142)$.

In the first, 2-oxo acids can be converted into branched aldehydes (2-methyl-butanal, 3-methyl-butanal, and 2-methyl-propanal, for Ile, Leu and Val, respectively) by oxidative carboxylation by an $\alpha$-keto acid decarboxylase enzyme (for example pyruvate decarboxylase, PDC) $(18,30$, $140,142,143,147)$. These aldehydes can be reduced to their corresponding branched alcohol (2-methyl-butanol, 3-methyl-butanol and 2-methyl-propanol) by action of the $\mathrm{ADH}$ enzyme, which uses NAD $(\mathrm{P})^{+}$as a cofactor $(30,140,143,145$, 147). The transformation of amino acids into alcohols is known as the Ehrlich pathway, in which the key enzymes are transaminases, decarboxylases and dehydrogenases (148). Branched aldehydes can also be oxidized to their corresponding branched fatty acid (2-methyl-butanoic, 3-methyl-butanoic and 3-methyl-propanoic) by the action of aldehyde dehydrogenase (AldDH) $(30,140,143,147)$, which uses $\mathrm{NAD}(\mathrm{P}) \mathrm{H}$ as a cofactor.

In the second, 2-oxo acids can be converted to fatty acids by oxidative decarboxylation. First, the $\alpha$-keto acid is irreversibly converted to a branched-chain acyl-CoA (2-methyl butanoil-CoA, 4-methyl butyl-CoA and 2-methyl propyl-CoA from Ile, Leu and Val, respectively) (141, 149 ) by the action of branched-chain $\alpha$-keto acid dehydrogenase (BCKDH), which substitutes a $\mathrm{CO}_{2}$ from the 2-oxo acid for the CoA cofactor with $\mathrm{NAD}^{+}$reduction (140). Then, the acyl-CoA can be converted to a fatty acid by phosphate acetyltransferase (PAT) $(18,140)$. Branched fatty acids can be transformed into alcohols and esters by the reduction of the acid to its corresponding aldehyde (67). Alcohols formed by the Ehrlich pathway can be es- terified with acyl-CoA by AAT to form branched-chain esters $(8,17,137)$.

In plant tissues (90) and in yeasts (150), it has been reported that 2-methyl-2-butenyl-CoA derived from the catabolism of Ile can be degraded to acetyl-CoA and propyl-CoA through $\beta$-oxidation reactions (90). However, these esters derived from Ile by this pathway have not been reported in apples. In melon, the formation of propanoate from 2-methylbutyl by the addition of Ile has been reported (31).

In the third pathway, $\alpha$-oxo acids can also be reduced to hydroxy acids by a hydroxyacid dehydrogenase (HDH), which is specific for each $\alpha$-oxo acid $(18,142,145)$. Hydroxy acids do not contribute to aroma, but they allow the conversion of NADH to $\mathrm{NAD}^{+}(140)$.

Fig. 3 shows the formation of volatile compounds from the catabolism of L-isoleucine $(17,18,31,67,90,140,142$, $143,151)$. The levels of precursor amino acids do not always explain the formation of the corresponding esters, therefore, it has been suggested that the selectivity of enzymes preceding AAT has an important role in the composition of the formed esters (49).

\section{Terpenoids and phenylpropenes}

Terpenoids are synthesized via two parallel pathways: (i) mevalonate (MVA) pathway, which operates in the cytosol and starts with the condensation of two acetyl-CoA molecules, and (ii) methylerythritol phosphate (MEP) pathway active in the plastids, which starts with pyruvate and glyceraldehyde 3-phosphate as precursors to form 1-deoxyxylulose 5-phosphate. Both MVA and MEP routes result in the formation of isopentyl diphosphate (IPP) and its isomer dimethylallyl diphosphate (DMADP), intermediaries from which all terpenes are derived. Sesquiterpenes (C15) and triterpenes are produced via MVA pathway, while monoterpenes (C10), diterpenes (C20) and tetraterpenes (C40) are produced via MEP pathway $(3,63,64,68,69$, $152,153)$. The catalytic conversion of the terpene precursors is carried out by terpene synthase enzymes. Nieuwenhuizen et al. (154) reported that genome of cultivated apple (Malus domestica) contains 55 putative terpene synthase genes, ten of which appear to be functional.

Monoterpenes and sesquiterpenes are the main fruit aroma components from the isoprenoid family in the apple fruit. The acyclic branched sesquiterpene (E,E)- $\alpha$ -farnesene, synthesized predominantly in epidermal and hypodermal cell layers of the fruit (155), is the most associated with ripe apple fruit $(154,156,157)$. However, $\alpha$-farnesene has also been associated with superficial scald in the skin of several apple cultivars (155). According to Pechous and Whitaker (158) (E,E)- $\alpha$-farnesene is produced during storage of apple and its production decreases after about 2 months of storage. Other terpenes occur in very low amounts in fruit and floral and vegetative tissues.

In Mela Rossa Val Metauro wild apple the main volatiles were terpenes, with $\alpha$-farnesene as the most prominent (159). In Earligold apple, Rapparini et al. (160) identified 15 monoterpenes, with limonene, $p$-cymene, camphor, linalool, $\delta$-carene, $\alpha$-pinene and $\alpha$-terpinene as the main compounds. In Ponta do Pargo, Porto Santo and Santo da 


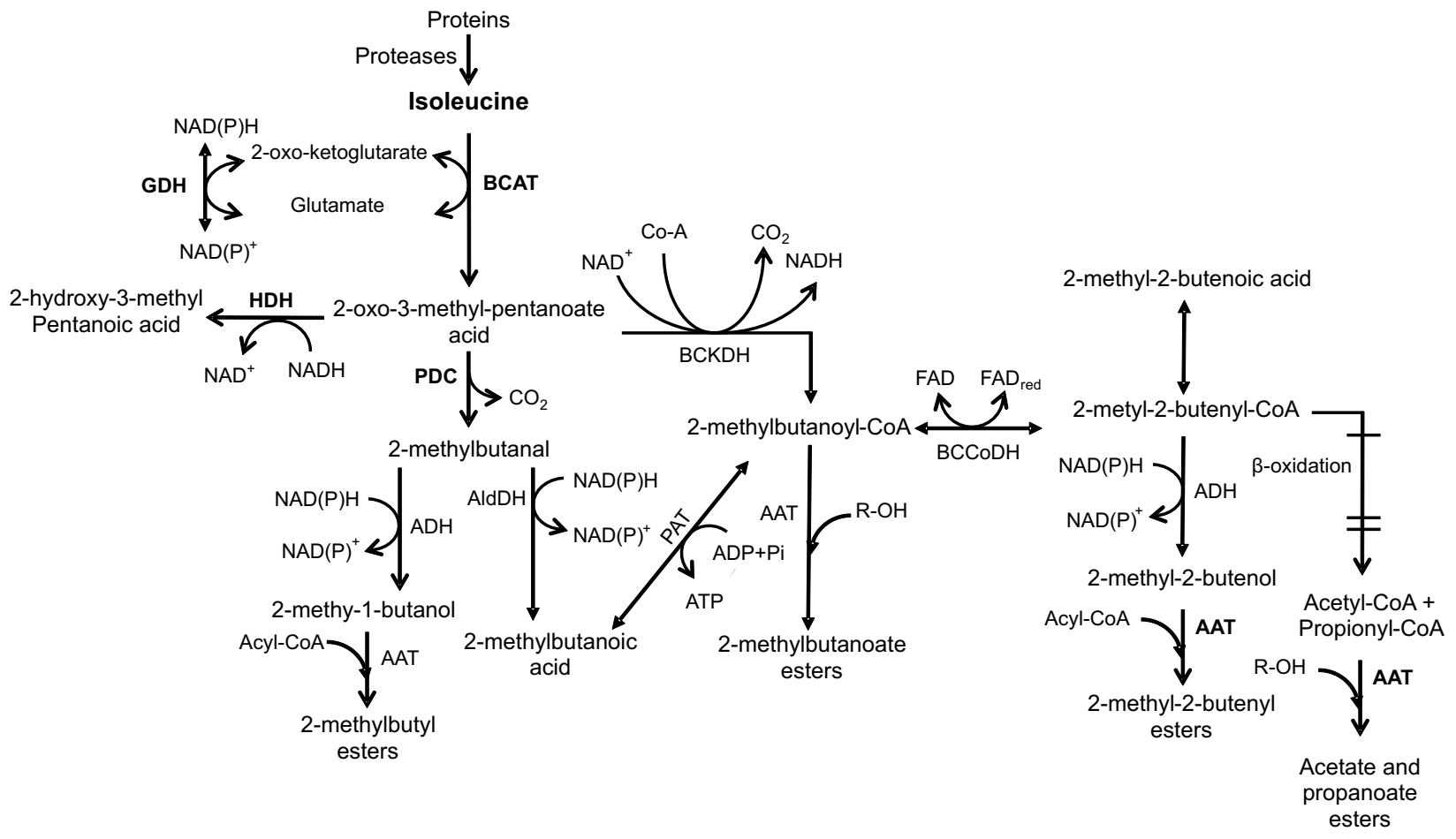

Fig. 3. Biosynthesis of volatile aroma compounds from isoleucine catabolism. Adaptation based on 17,18,31,67,90,140,142,143,151. BCAT=branched-chain amino acid transferase, GDH=glutamate dehydrogenase, PDC=piruvate decarboxylase, BCKD=branched-chain $\alpha$-ketoacid dehydrogenase, $\mathrm{HDH}=2$-hydroxy-3-methyl-pentanoic acid dehydrogenase, $\mathrm{BCCoDH}=2$-methyl branched-chain acyl-CoA dehydrogenase, $\mathrm{PAT}=$ phosphate acetyltransferase, AldDH=aldehyde dehydrogenase, $\mathrm{ADH}=$ alcohol dehydrogenase, $\mathrm{AAT}=$ alcohol acyltransferase

Serra apples, terpenes constituted a significant fraction of total volatile compounds, with $\alpha$-farnesene as the main compound (an average of $25 \%$ ). Other terpenes identified were $\beta$-farnesene, germacrene, farnesol and estragole (161). In Royal Gala, a low terpene producer, (E,E)-farnesol was the predominant terpene ( $84 \%$ of total terpenes), while in King David, Wilmot, Russet, Belle et Bonne, Adam's Pearmain and Merton Russet apples, (E,E)- $\alpha-$ -farnesene was by far the most prevalent (161).

Phenylpropenes, such as eugenol, estragole and isoestragole, also contribute to apple flavour and aroma. These compounds are derived from the phenylpropanoid pathway (162). Estragole imparts a spicy/aromatic flavour to some apple varieties like Ellison's Orange, D'Arcy Spice and Fenouillet, and an aniseed note to fresh Royal Gala apple (162).

\section{Factors Affecting the Production of Volatiles}

There are several factors that affect the synthesis of volatile aromatic compounds in apple. These factors may be classified as preharvest, harvest or postharvest factors, depending on the period of time during apple growth when they are relevant. The effect of these factors on the production of aroma volatiles in apple is described in this section.

\section{Preharvest factors}

The aroma of an apple greatly depends on the variety. Differences in the concentrations of volatile com- pounds among different apple varieties give them a characteristic aroma pattern $(4,12)$. Table 2 shows the main aromatic volatile compounds in different apple varieties. It shows that 2-methylbutyl acetate is the main ester in apples such as Bisbee Red Delicious (10), Redchief Delicious (35) and Fuji $(48,123)$, whereas butyl acetate is the main ester in Golden Delicious $(163,164)$, Royal Gala (165) and Mondial Gala apples $(53,124)$.

Environmental factors can also affect the composition of volatiles in apples. Likewise, it has been reported that the profile of volatile compounds can be affected by the weather (166), geographic location (167) and cultural practices (168).

Although the aroma of apples is a highly heritable feature only minimally influenced by the harvest, Dunemann et al. (52) reported that a variety can develop a different aromatic compound profile in different production years $(14,34,169)$.

The volatile compounds of the aroma are not produced in significant amounts during apple growth, but they increase during the climacteric period, when the production of ethylene induces a series of physical and chemical changes in the expression of certain genes and the activity of certain enzymes $(170,171)$. While total esters are found in very low concentrations when endogenous ethylene levels are low, ester production increases rapidly as soon as ethylene synthesis starts (75). Given that the production of esters is regulated by ethylene (172), inhibitors of this hormone added in the preharvest stage reduce the production of volatiles in the fruit. 
1-Methylcyclopropene (1-MCP) is a powerful ethylene inhibitor. It has been observed that its application reduces the production of volatiles in apples of different varieties such as Golden Delicious (173), Fuji (174), Gala (175), Anna (176) and Greensleeves transgenic apple $(44,172)$. 1-MCP reduces the transcription and translation of the gene MdAAT2 in Golden Delicious apples with a subsequent decrease in the production of esters (127). Aminoethoxyvinylglycine, another inhibitor of ethylene production, has also been shown to reduce volatiles in apples $(164,177-179)$.

\section{Harvest factors}

The concentration of volatile compounds in apple greatly increases as maturation advances $(15,180)$. Maturity at the time of harvest is one of the main factors affecting the quality of the apple during and after storage. Harvesting of apples before physiological maturity normally implies low volatile levels (181-183). An apple harvested in a climacteric stage will produce more volatiles during storage compared to preclimacteric fruit or overly mature fruit $(164,184,185)$.

\section{Postharvest factors}

Apples can be successfully stored under regular or controlled atmosphere for several months (186). However, storage conditions may reduce volatile compound biosynthesis in apples $(184,187)$ depending on the type of storage atmosphere employed and the length of the storage period $(184,188)$. Modified atmospheres, especially those with ultra-low oxygen $\left(p\left(\mathrm{O}_{2}\right)<1 \mathrm{kPa}\right)$, cause a reduction in the biosynthesis of linear chain volatiles due to a reduction in the concentration of alcohols and their esters $(37,179)$, except for ethanol and its derivatives, which are produced in apple under anaerobic conditions $(10,187)$. The synthesis and degradation of fatty acids also decline $(15,17,184)$ due to the reduction in $\beta$-oxidation, LOX activity and ethylene biosynthesis (22). However, the availability of substrates, more than the lack of enzymatic activity, is the most important factor in the suppression of volatile compounds during and after storage under controlled atmosphere $(48,53,123,124)$. Low oxygen concentration during storage has little effect on the biosynthesis of branched esters $(22,35,179,187)$.

On the other hand, a storage atmosphere with high $\mathrm{CO}_{2}$ concentration suppresses the production of linear and branched aromatic compounds, probably by inhibiting tricarboxylic acid, from which certain precursor amino acids derive (184). The reduction in aroma production can also be due to a low respiration rate in apples under controlled atmosphere, which can deplete stored energy metabolites such as ATP and NADPH, required for the biosynthesis and desaturation of fatty acids $(189,190)$.

During postharvest, concentration of esters may decrease due to their hydrolyzation by carboxylesterases to form their respective acids and alcohols, and by their diffusion in the environment (37-41). However, a low ester content can be caused rather by the lack of alcohols as precursors than by esterase activity, or diffusion (15,37, 191).

\section{Addition of Biosynthetic Precursors of Volatile Compounds to Apples}

The exogenous application of precursors is an alternative strategy for aroma regeneration in refrigerated apples. Substrate availability is an important factor in the recovery of aroma in apples stored for long periods (15, $36,124)$. It has been demonstrated that precursors added to whole apples diffuse towards the internal tissues of the fruit (46). However, the exogenous application of substrates in apple has been used more to elucidate the metabolic pathways $(16,17,192)$ than to increase the production of volatile compounds (193).

Precursors of volatile compounds have been added to different tissues of apples, and although intact apples and tissue samples metabolize substrates in the same way, most researchers prefer to use the intact fruit $(17,137,163)$. An intact apple and tissues are placed in a closed glass container, and substrate vapours diffuse through the tissue. The volatile compounds released by the fruit are carried by a continuous air current and recovered with a trap for subsequent analysis using gas chromatography. The incubation period lasts 24 hours or more and the evaluation period lasts several days $(9,16,17,43,46,179)$. The use of cortical or epidermal tissue disks, usually 9 to $12 \mathrm{~mm}$ in diameter and 1 to $3 \mathrm{~mm}$ thick, has the advantage of allowing easier access of the precursors, reducing the incubation time to less than 24 hours. However, its disadvantage is the requirement of a buffering system to maintain the viability of the fruit cells (194). The recovery of the volatile compounds can be performed by dynamic $(16,17,67$, $195)$ or static headspace $(127,196,197)$, and the volatile compounds are analyzed by gas chromatography. The addition of fatty acids, amino acids, aldehydes and alcohols stimulates the biosynthesis of volatile compounds in different apple varieties.

\section{Fatty acid addition}

The addition of fatty acids causes the formation of aldehydes, alcohols and their corresponding esters, in addition to the formation of new shorter fatty acids by the $\beta$-oxidation pathway, which stimulates a wide range of volatile compounds $(43,47)$. The optimal fatty acid concentration to be added decreases with the length of the chain. The addition of fatty acids at a concentration above the optimum can cause a decrease in the biosynthesis of aldehydes and alcohols, and at very high concentrations, fatty acids can cause browning of the tissues and acetaldehyde formation (47).

The addition of propionic acid to Golden Delicious apples that were stored for 8 months under controlled atmosphere led to the formation of propanal and propyl and propionate esters, usually absent from the fruit. However, no change in the total concentration of volatiles occurred. On the other hand, butanoic acid was converted to butanoate esters (46). In this variety, which was stored for 7 months under low oxygen concentration conditions, butanoic acid increased the biosynthesis of ethyl esters and butyl butyrate (184).

The addition of fatty acids with $2-5$ carbons to Golden Delicious apples stored under regular or controlled atmosphere for two months was found to cause an increase 
in the content of aldehydes corresponding to these acids, except for those of acetic acid and aldehydes derived from the $\beta$-oxidation of endogenous fatty acids. Under regular atmosphere, aldehydes are transformed to esters, but under controlled atmosphere, apparently the increased $\mathrm{CO}_{2}$ content causes a change in ADH activity, with a reduction in alcohol that limits the production of esters (9).

In whole Red Delicious and Granny Smith apples, linoleic or hexanoic acid was added in a mixture of saturated (C14:0, C16:0 and C18:0) or monounsaturated fatty acids (C17:1 and C18:1) labelled with deuterium. The deuterium-labelled linoleic acid formed hexyl acetate (16 $\%)$ and hexanoate esters, mostly ethyl (47\%) and propyl hexanoate $(20 \%)$, demonstrating that the LOX pathway is active in intact fruit. The deuterium-labelled hexanoic acid formed hexyl acetate and 1-hexanol, and through $\beta$-oxidation, 1-butanol and butyl and butanoate esters, while through $\alpha$-oxidation pentyl and pentanoate esters were formed (16). The saturated and monounsaturated fatty acids were transformed into hexyl acetate esters (50 and $47 \%$ ), hexanoate esters (38 and $33 \%$ ) and octanoate esters (50 and $47 \%$ ), probably produced through fatty acid $\beta$-oxidation (16). Previously, the addition of deuterium-labelled 2-methylbutanoic acid to Red Delicious apples produced 2-methylbutanoate esters (58\%), mostly hexyl 2-methylbutanoate (42\%) and 2-methylbutyl esters (38\%), mostly 2-methylbutyl acetate (26\%). In Granny Smith apples, ethyl 2-methylbutanoate was primarily synthesized (84\%) (17).

Fatty acids in the form of fatty acid sodium salts with 4-18 carbon atoms have also been added to cortical or epidermal tissue disks from recently harvested Calvilla apples. Fatty acids with an odd number of carbons formed propanol and pentanol, whereas those with an even number formed butanol and hexanal. Although the concentration of saturated acids with 12-18 carbon atoms was very low, hexanal production increased slightly with C18:1 and markedly with C18:2 fatty acids. Alcohol production was higher in the skin. Although yellow varieties mostly produce acetic acid esters and red varieties butyric acid esters, in Golden Delicious apples, butyric acid is quickly and completely transformed by $\beta$-oxidation into acetic acid, forming acetate esters (47).

\section{Amino acid addition}

The addition of amino acids increases the production of volatile compounds with a structure similar to that of the side chain of the added amino acid (31). Even though amino acids are a secondary source of substrates for the biosynthesis of volatile compounds in apples, very few studies have reported the addition of amino acids as substrates for the production of volatile compounds in this fruit $(17,66,67)$. Several amino acids such as leucine, valine, phenylalanine (65) and isoleucine (198) have been added to plantain, and methionine has been added to melon (31).

In Golden Delicious apples stored for 9 months under controlled atmosphere, a solution of L-isoleucine was injected into the central cavity. The isoleucine was converted to 2-methyl-1-butanol and 2-methylbutyl esters, mostly 2-methylbutyl acetate, and to 2-methyl-2-butenyl and 2-methylbutanoate esters (66).

The incubation of Red Delicious apple cubes stored for 5 months under controlled atmosphere with L-isoleucine- $d_{10}$ formed 2-methylbutanoate esters (mostly ethyl 2-methylbutanoate, $51 \%$ ), 2-methylbutyl esters (mostly 2-methylbutyl acetate, $35 \%$ ), and 2-methyl-2-butenyl acetate esters ( $2 \%)$. On the other hand, in Granny Smith apple skins, L-isoleucine- $d_{10}$ treatment produced mostly ethyl 2-methylbutanoate ester (99\%) and 2-methylbutanol $(1 \%)$ in a similar proportion to that with the addition of 2-methylbutanoic acid in both varieties (17). The incubation of Red Delicious cubes with L-isoleucine- $d_{10}$ during five months of storage increased the concentration of 2-methylbutanoic acid and ethyl 2-methylbutanoate ester, but there were very low concentrations of 2-methyl-1-butanol and 2-methylbutyl acetate esters (hexyl 2-methylbutanoate and 2-methyl-2-butenyl acetate), probably due to ATT specificity in this variety (67). These reports indicate that isoleucine is metabolized in apples by different pathways within the amino acid pathway (Fig. 3).

\section{Aldehyde addition}

In addition to contributing to apple aroma, aldehydes are intermediate compounds between fatty acids and alcohols (47). Vapours of aldehydes with 3 to 6 carbon atoms added to recently harvested intact Golden Delicious apples considerably increased the content of the corresponding acetate esters, indicating that they were efficiently converted to alcohols (195). Additionally, in Golden Delicious apples that were recently harvested or stored for 5 months under ultra-low oxygen conditions, butanal vapours induced the formation of butanol, butyl acetate and butyl butyrate (179). In fruit stored for 8 months under ultra-low oxygen conditions, butanal was transformed into butanol or butanoic acid, increasing the production of esters such as pentyl and butyl butanoate (184). In another study on Red Delicious and Granny Smith apples, deuterium-labelled trans-2-hexenal and cis-3-hexenal aldehydes, added as vapour, produced a mixture of hexyl esters (trans-3-hexenyl and cis-2-hexenyl) and 1-hexanol in both varieties. Moreover, only in Red Delicious apples, ethyl, propyl and butyl butanoate esters were formed and in Granny Smith trans-3-hexenol, cis-3-hexenol and trans-2-hexenol alcohols were exclusively formed (16). In these varieties, deuterium-labelled hexanal was converted to 1-hexanol and to hexyl and hexanoate esters (16).

\section{Alcohol addition}

Alcohols with 2-8 carbon atoms have been added alone or as a mixture. However, because high-molecular-mass substrates evaporate poorly and diffuse only weakly through cellular membranes $(37,46,83)$, the results obtained with 7- and 8-carbon alcohols have not been successful. Ester production is proportional to the concentration of the added alcohol, and the concentration of acyl-CoA is not a limiting factor $(43,192)$, although the difference in the aroma composition among varieties can be due to differences in the preference for acyl-CoA molecules (47). The fruit can efficiently catabolize alcohols with 8 or few- 
er carbons exogenously added after 8 months under ultra-low oxygen, suggesting that $\mathrm{ADH}$ remains active (184). However, after 7 months under ultra-low oxygen, intact Golden Delicious apples exposed to a mixture of alcohols synthesized only $20 \%$ of volatiles compared to apples stored under regular atmosphere (179). With the addition of an alcohol, mostly acetate esters are produced (43). However, at the same time, a decrease in the formation of other esters, especially those with 4 or more carbon atoms, can be observed in a kind of antagonism between substrates $(46,47,192)$. Given that the addition of a single alcohol at high concentration can inhibit the production of esters from other alcohols (194), these compounds have been added in equimolar solutions. However, the addition of alcohols leads to high alcohol concentration in tissues, which may deteriorate the apple (43).

Alcohols with 2-6 carbon atoms added individually to Golden Delicious (184) and as a mixture to Cox's Orange Pippin apples (83) were converted to their corresponding acetate esters, with butanol and pentanol being the quickest and most esterified in Cox's Orange Pippin apples. In another study with this variety, although hexanol formed hexyl acetate, ethanol did not produce ethyl acetate but accumulated in the tissues (37). However, Dixon (194) reports that ethanol forms ethyl acetate when added individually but not when added in a mixture. Ethanol and methanol added separately to Red Delicious apples form the corresponding ethyl and methyl esters (192). In Golden Delicious apples stored for 5 months under ultra-low oxygen and exposed to 3- to 6-carbon linear alcohols, isobutanol and isopentanol added separately increased the biosynthesis of acetate esters (mostly) and butanoate (to a lesser degree) (179).

Hexanol is one the most widely used alcohols for application in apples. In Red Delicious and Granny Smith apples, deuterium-labelled hexanal and trans-2-hexenol alcohols were exclusively transformed into hexyl esters (from acetate to hexanoate and 2-methylbutanoate). The same occurred with cis-3-hexenol in Granny Smith apples, whereas Red Delicious apples were incapable of reducing this alcohol to hexyl esters (16). The addition of deuterium-labelled 2-methylbutanol to Red Delicious apples formed 2-methylbutyl acetate esters (72\%) almost exclusively and hexanoate (14\%), whereas in Granny Smith apples, 2-methylbutyl esters (70 \% acetate, propionate and butanoate) and 2-methylbutanoate (7\%) were formed (17). Another study reported that 1-hexanol and 2-methyl-1-butanol were converted to acetate esters in Fuji apples, whereas in Granny Smith hexyl acetate was produced but 2-methyl-1-butanol was not metabolized (13).

Alcohols have also been added to tissues of apples from different varieties. In Golden Delicious skin disks treated with 1-pentanol, 1-hexanol, trans-2-hexenol and cis-2-hexenol 65 days after full flowering, cis- and trans-2-hexenyl acetate, butanoate and hexanoate esters were formed. Pentyl and hexyl esters were only formed 15 days after full flowering of fruit (127). In disks of different tissues from Red Chief Delicious apples, the addition of pentanol formed pentanal and pentyl acetate in higher concentrations, as well as pentyl propionate, butyrate, pentanoate and hexanoate esters at lower concentrations.
None of these compounds was present in untreated fruit. The production of volatiles decreased from the skin towards the centre of the fruit (197). In other studies, the addition of 1- to 6-carbon linear alcohols to pulp disks and skin from recently harvested Red Delicious apples achieved the maximum production of esters with 1-butanol converting to butyl and butanoate esters and 1-pentanol converting almost exclusively to pentyl esters, while methanol and ethanol had very low esterification rate (192). All alcohols formed acetate esters, and ethanol, propanol and butanol also formed their corresponding aldehydes (192).

Primary 2- to 6-carbon alcohols, when added separately or in equimolar solution to apple skin disks, were converted to their acetate ester in nine apple varieties including Fuji, Golden Delicious, Red Delicious, Granny Smith and Cox's Orange Pippin (194). In skin disks of this last variety, in addition to primary 2- to 6-carbon alcohols, 2-methyl-1-propanol and 2-methyl-1-butanol also formed acetate esters and 1-butanol also formed butyl butanoate ester, whereas 2-propanol and 2-butanol did not form any new product (37). Also, the addition of deuterium-labelled hexanol and 2-methyl-1-butanol to diced Red Delicious apples stored for 5 months under controlled atmosphere increased the production of their corresponding acetate esters (67).

\section{Ester addition}

Aldehydes and fatty acids are difficult to manipulate (43), so esters of short-chain fatty acids have been used as precursor sources in apples because they can diffuse more easily. In apples, esters are hydrolyzed by carboxylesterase, releasing the fatty acid and the corresponding alcohol (43). It has been suggested that these enzymes remain active in apples even after 8 months of storage under ultra-low oxygen conditions (184).

In Cox's Orange Pippin apples, methyl heptanoate was mostly converted to pentyl acetate, and at 10- to 20-fold lower concentrations to propyl acetate, whereas the production of heptyl acetate was insignificant or absent, confirming that heptanoic acid completes one or two $\beta$-oxidation cycles. The same occurred when other methyl esters with a fraction of 4- to 8-carbon acids were added. Methyl octanoate was converted to butyl and hexyl acetate and propyl and butyl butanoate (43). On the other hand, the exposure of Red Delicious and Granny Smith apples to ethyl 2-methylbutanoate- $d_{3}$ vapours formed 2-methylbutanoate esters, mostly butyl-2-methyl butanoate (18 and $49 \%$ in Red Delicious and Granny Smith, respectively) and hexyl-2-methyl butanoate (17 and $27 \%$ ). However, Red Delicious formed 2-methylbutane esters (mostly acetate, $49 \%$ ) and 2-methyl-2-butenyl esters (mostly acetate, $2 \%$ ), while in Granny Smith only traces of the former where detected and the latter were not detected at all (17).

The exposure of Calvilla, Golden Delicious and Starking apple skin disks to methyl ether (butanoate to hexanoate) caused the release of fatty acids, and those with more than 4 carbons completed 1 or $2 \beta$-oxidation cycles, with the loss of 2 carbons in each cycle, forming acetate esters with the corresponding alkyl fraction (acetate esters from propyl to hexyl) (47). 


\section{Conclusions}

The production of volatile aroma compounds in apples is the result of a combination of complex metabolic pathways with diverse physiological processes and control mechanisms in the fruit metabolism. Their production also varies due to genetic factors, culture practices, crop maturity and storage conditions. Especially important is the effect of compounds that suppress ethylene production such as 1-methylcyclopropene, as is the reduction in the respiration rate at low $\mathrm{O}_{2}$ and/or high $\mathrm{CO}_{2}$ atmosphere. In these cases, a decrease in the production of adenosine triphosphate molecules reduces the synthesis of fatty acids, the main precursors of volatile compounds. As demonstrated, although the availability of substrates for the production of volatile compounds is a critical factor, it is not the only one affecting the aroma of apples, and it can be controlled in both whole and cut apples. However, up to this point, there is little knowledge regarding the metabolic pathways, the genes encoding the enzymes involved, the mechanisms controlling genetic expression and enzymatic activity, or even the exact metabolism of exogenously added precursors, especially in freshly cut apples. The exogenous addition of substrates for the production of volatile compounds is an area of potential development, especially in lightly processed apples (sliced, in cubes or cylinders), given the increasing demand for freshly cut fruit on the market. All these are areas of opportunity in which better knowledge can help us understand, and therefore exploit, the production of volatile compounds in the apple.

\section{References}

1. Bonany J, Buehler A, Carbó J, Codarin S, Donati F, Echeverria $G$, et al. Consumer eating quality acceptance of new apple varieties in different European countries. Food Qual Prefer. 2013;30:250-9.

http://dx.doi.org/10.1016/j.foodqual.2013.06.004

2. Baldwin EA. Fruit and vegetable flavor. In: Gross KC, Wang CY, Saltveit MA, editors. Handling, transportation and storage of fruits, vegetables, and florist and nursery stock. Washington, DC, USA: United States Department of Agriculture (USDA), Agriculture Handbook; 2002. p. 66.

3. Pérez AG, Sanz C. Formation of fruit flavour. In: Brückner B, Wyllie SG, editors. Fruit and vegetable flavour. Boca Raton FL, USA: CRC Press; 2008. pp. 71-102.

4. Cunningham DG, Acree TE, Barnard J, Butts RM, Braell PA. Charm analysis of apple volatiles. Food Chem. 1986;19:13747.

http://dx.doi.org/10.1016/0308-8146(86)90107-X

5. Sanz C, Olías JM, Pérez AG. Aroma biochemistry of fruits and vegetables. In: Tomás Barberán FA, Robins RJ, editors. Phytochemistry of fruits and vegetables. Oxford, UK: Clarendon Press; 1997. pp. 125-255.

6. Dimick PS, Hoskin JC, Acree TE. Review of apple flavorstate of the art. Crit Rev Food Sci. 1983;18:387-409.

7. Forney CF. Postharvest issues in blueberry and cranberry and methods to improve market-life. Acta Hortic. 2009;810:78598.

http://dx.doi.org/10.17660/ActaHortic.2009.810.105

8. Paillard NMM. The flavour of apples, pears and quinces. In: Morton IE, Macleod AJ, editors. Food Flavours, Part C. The flavour of fruits. Amsterdam, The Netherlands: Elsevier Science; 1990. pp. 1-41.
9. De Pooter H, Van Acker MR, Schamp NM. Aldehyde metabolism and the aroma quality of stored Golden Delicious apples. Phytochemistry. 1986;26:89-92. http://dx.doi.org/10.1016/S0031-9422(00)81487-9

10. Mattheis JP, Fellman JK, Chen PM, Patterson ME. Changes in headspace volatiles during physiological development of Bisbee Delicious apple fruits. J Agric Food Chem. 1991;39: 1902-6. http://dx.doi.org/10.1021/jf00011a002

11. Flath RA, Black DR, Guadagni DG, McFadden WH, Schultz TH. Identification and organoleptic evaluation of compounds in Delicious apple essence. J Agric Food Chem. 1967;15:29-35. http://dx.doi.org/10.1021/jf60149a032

12. Kakiuchi N, Moriguchi S, Fukuda H, Ichimura N, Kato $Y$, Banba Y. Composition of volatile compounds of apple fruits in relation to cultivars. J Jpn Soc Hortic Sci. 1986;55:280-9. http://dx.doi.org/10.2503/jjshs.55.280

13. Holland D, Larkov O, Bar-Ya'akov I, Bar E, Zax A, Brandeis $\mathrm{E}$, et al. Developmental and varietal differences in volatile ester formation and acetyl-CoA: alcohol acetyl transferase activities in apple (Malus domestica Borkh.) fruit. J Agric Food Chem. 2005;53:7198-203. http://dx.doi.org/10.1021/jf050519k

14. López ML, Lavilla MT, Riba M, Vendrell M. Comparison of volatile compounds in two seasons in apples: Golden Delicious and Granny Smith. J Food Quality. 1998;21:155-66. http://dx.doi.org/10.1111/j.1745-4557.1998.tb00512.x

15. Fellman JK, Miller TW, Mattinson DS, Mattheis JP. Factors that influence biosynthesis of volatile flavor compounds in apple fruits. HortSci. 2000;35:1026-33.

16. Rowan DD, Allen JM, Fielder S, Hunt MB. Biosynthesis of straight-chain ester volatiles in Red Delicious and Granny Smith apples using deuterium-labeled precursors. J Agric Food Chem. 1999;47:2553-62. http://dx.doi.org/10.1021/jf9809028

17. Rowan DD, Lane HP, Allen JM, Fielder S, Hunt MB. Biosynthesis of 2-methylbutyl, 2-methyl-2-butenyl, and 2-methylbutanoate esters in Red Delicious and Granny Smith apples using deuterium-labeled substrates. J Agric Food Chem. 1996;44:3276-85.

http://dx.doi.org/10.1021/jf9508209

18. Liu M, Nauta A, Francke C, Siezen RJ. Comparative genomics of enzymes in flavor-forming pathways from amino acids in lactic acid bacteria. Appl Environ Microb. 2008;74:4590600.

http://dx.doi.org/10.1128/AEM.00150-08

19. Vallat $\mathrm{A}, \mathrm{Gu} \mathrm{H}$, Dorn $\mathrm{S}$. How rainfall, relative humidity and temperature influence volatile emissions from apple trees in situ. Phytochemistry. 2005;66:1540-50. http://dx.doi.org/10.1016/j.phytochem.2005.04.038

20. Mattheis JP, Fan X, Argenta LC. Interactive responses of Gala apple fruit volatile production to controlled atmosphere storage and chemical inhibition of ethylene action. J Agric Food Chem. 2005;53:4510-6. http://dx.doi.org/10.1021/jf050121o

21. Aprea E, Corollaro ML, Betta E, Endrizzi I, Demattè ML, Biasioli F, Gasperi F. Sensory and instrumental profiling of 18 apple cultivars to investigate the relation between perceived quality and odour and flavour. Food Res Int. 2012;49:677-86. http://dx.doi.org/10.1016/j.foodres.2012.09.023

22. Both V, Brackmann A, Thewes FR, de Freitas Ferreira D, Wagner R. Effect of storage under extremely low oxygen on the volatile composition of 'Royal Gala' apples. Food Chem. 2014;156:50-7.

http://dx.doi.org/10.1016/j.foodchem.2014.01.094

23. Dixon J, Hewett EW. Exposure to hypoxia conditions alters volatile concentrations of apple cultivars. J Sci Food Agr. 2000;81:22-9. 
http://dx.doi.org/10.1002/1097-0010(20010101)81:1<22::AIDJSFA769>3.0.CO;2-9

24. Lopez ML, Lavilla MT, Recasens I, Graell J, Vendrell M. Changes in aroma quality of 'Golden Delicious' apples after storage at different oxygen and carbon dioxide concentrations. J Sci Food Agr. 2000;80:311-24.

http://dx.doi.org/10.1002/1097-0010(200002)

25. HSDB ${ }^{\circledR}$. Hazardous Substances Data Bank. Bethesda, MD, USA: US National Library of Medicine; 2015. Available from: http://www.nlm.nih.gov/pubs/factsheets/hsdbfs.html.

26. Mehinagic E, Prost C, Demaimay M. Optimization of extraction of apple aroma by dynamic headspace and influence of saliva on extraction of volatiles. J Agric Food Chem. 2004;52: 5175-82. http://dx.doi.org/10.1021/jf049577g

27. Takeoka GR, Buttery RG, Flath RA. Volatile constituents of Asian pear (Pyrus serotina). J Agric Food Chem. 1992;40: 1925-9. http://dx.doi.org/10.1021/jf00022a040

28. Bartley IM, Hindley SJ. Alcohol dehydrogenase of apple. J Exp Bot. 1980;31:449-59. http://dx.doi.org/10.1093/jxb/31.2.449

29. D'Auria, S. Alcohol dehydrogenase. In: Whitaker JR, Voragen AGJ, Wong DWS, editors. Handbook of food enzymology. Boca Raton, FL, USA: CRC Press; 2003.

30. Dickinson JR, Lanterman MM, Danner DJ, Pearson BM, Sanz P, Harrison SJ, Hewlins MJ. A ${ }^{13} \mathrm{C}$ nuclear magnetic resonance investigation of the metabolism of leucine to isoamyl alcohol in Saccharomyces cerevisiae. J Biol Chem. 1997;272: 26871-8. http://dx.doi.org/10.1074/jbc.272.43.26871

31. Gonda I, Bar E, Portnoy V, Lev S, Burger J, Schaffer AA, et al. Branched-chain and aromatic amino acid catabolism into aroma volatiles in Cucumis melo L. fruit. J Exp Bot. 2010;61: 1111-23. http://dx.doi.org/10.1093/jxb/erp390

32. Reineccius G. Flavor chemistry and technology. Boca Raton, FL, USA: CRC Press; 2006.

33. López Fructuoso ML, Echeverría Cortada G. Apple (Malus $\times$ domestica Borkh). In: Hui YH, editor. Handbook of fruit and vegetable flavors. Hoboken, NJ, USA: John Wiley \& Sons, Inc; 2010. pp. 247-64.

34. Echeverría G, Graell J, López ML, Lara I. Volatile production, quality and aroma-related enzyme activities during maturation of 'Fuji' apples. Postharv Biol Technol. 2004;31: 217-27.

http://dx.doi.org/10.1016/j.postharvbio.2003.09.003

35. Fellman JK, Rudell DR, Mattinson DS, Mattheis JP. Relationship of harvest maturity to flavor regeneration after CA storage of 'Delicious' apples. Postharv Biol Technol. 2003;27:3951. http://dx.doi.org/10.1016/S0925-5214(02)00193-X

36. Ló López ML, Lavilla T, Recasens I, Riba M, Vendrell M. Influence of different oxygen and carbon dioxide concentrations during storage on production of volatile compounds by Starking Delicious apples. J Agric Food Chem. 1998;46: 634-43. http://dx.doi.org/10.1021/jf9608938

37. Knee M, Hatfield SG. The metabolism of alcohols by apple fruit tissue. J Sci Food Agr. 1981;32:593-600. http://dx.doi.org/10.1002/jsfa.2740320611

38. Goodenough PW, Entwistle TG. The hydrodynamic properties and kinetic constants with natural substrates of the esterase from Malus pumila fruit. FEBS J. 1982;127:145-50. http://dx.doi.org/10.1111/j.1432-1033.1982.tb06848.x

39. Ileperuma NR, Marshall SDG, Squire CJ, Baker HM, Oakeshott JG, Russell RJ, et al. High-resolution crystal structure of plant carboxylesterase AeCXE1, from Actinidia eriantha, and its complex with a high-affinity inhibitor paraoxon. Biochemistry. 2007;46:1851-9.

http://dx.doi.org/10.1021/bi062046w

40. Schaffer RJ, Friel EN, Souleyre EJF, Bolitho K, Thodey K, Ledger $\mathrm{S}$, et al. A genomics approach reveals that aroma production in apple is controlled by ethylene predominantly at the final step in each biosynthetic pathway. Plant Physiol. 2007;144:1899-912.

http://dx.doi.org/10.1104/pp.106.093765

41. Souleyre EJF, Marshall SDG, Oakeshott JG, Russell RJ, Plummer KM, Newcomb RD. Biochemical characterisation of MdCXE1, a carboxylesterase from apple that is expressed during fruit ripening. Phytochemistry. 2011;72:564-71. http://dx.doi.org/10.1016/j.phytochem.2011.01.020

42. St-Pierre B, De Luca V. Evolution of acyltransferase genes, origin and diversification of the BAHD superfamily of acyltransferases involved in secondary metabolism. In: Romeo JT, Ibrahim R, Varin L, De Luca V, editors. Recent advances in phytochemistry, vol. 34: Evolution of metabolic pathways. Oxford, UK: Elsevier Science Ltd; 2000. pp. 285-315. http://dx.doi.org/10.1016/S0079-9920(00)80010-6

43. Bartley IM, Stoker PG, Martin ADE, Hatfield SGS, Knee M. Synthesis of aroma compounds by apples supplied with alcohols and methyl esters of fatty acids. J Sci Food Agr. 1985; 36:567-74. http://dx.doi.org/10.1002/jsfa.2740360708

44. Defilippi BG, Kader AA, Dandekar AM. Apple aroma: alcohol acyltransferase, a rate limiting step for ester biosynthesis, is regulated by ethylene. Plant Sci. 2005;168:1199-210. http://dx.doi.org/10.1016/j.plantsci.2004.12.018

45. Altisent R, Graell J, Lara I, López L, Echeverría G. Increased straight-chain esters content after ultra low oxygen storage and its relation to the lipoxygenase system in 'Golden Reinders $^{\circledR \prime}$ apples. Eur Food Res Technol. 2011;232:51-61. http://dx.doi.org/10.1007/s00217-010-1359-7

46. De Pooter HL, Dirinck PJ, Willaert GA, Schamp NM. Metabolism of propionic acid by Golden Delicious apples. Phytochemistry. 1981;20:2135-38. http://dx.doi.org/10.1016/0031-9422(81)80100-8

47. Paillard NM. Biosynthesis of apple volatiles: formation of alcohols and esters from fatty acids. Phytochemistry. 1979;18: 1165-71 (in French). http://dx.doi.org/10.1016/0031-9422(79)80127-2

48. Echeverría G, Fuentes T, Graell J, Lara I, López ML. Aroma volatile compounds of 'Fuji' apples in relation to harvest date and cold storage technology: A comparison of two seasons. Postharv Biol Technol. 2004;32:29-44. http://dx.doi.org/10.1016/j.postharvbio.2003.09.017

49. Beekwilder J, Alvarez-Huerta M, Neef E, Verstappen FW, Bouwmeester HJ, Aharoni A. Functional characterization of enzymes forming volatile esters from strawberry and banana. Plant Physiol. 2004;135:1865-78. http://dx.doi.org/10.1104/pp.104.042580

50. El-Sharkawy I, Manríquez D, Flores FB, Regad F, Bouzayen M, Latché A, Pech JC. Functional characterization of a melon alcohol acyl-transferase gene family involved in the biosynthesis of ester volatiles. Identification of the crucial role of a threonine residue for enzyme activity. Plant Mol Biol. 2005; 59:345-62. http://dx.doi.org/10.1007/s11103-005-8884-y

51. Souleyre EJ, Greenwood DR, Friel EN, Karunairetnam S, Newcomb RD. An alcohol acyl transferase from apple (cv. Royal Gala), MpAAT1, produces esters involved in apple fruit flavor. FEBS J. 2005;272:3132-44. http://dx.doi.org/10.1111/j.1742-4658.2005.04732.x

52. Dunemann F, Ulrich D, Malysheva-Otto L, Weber W, Longhi S, Velasco R, Costa F. Functional allelic diversity of the apple alcohol acyl-transferase gene MdAAT1 associated with fruit 
ester volatile contents in apple cultivars. Mol Breeding. 2012; 29:609-25.

http://dx.doi.org/10.1007/s11032-011-9577-7

53. Echeverría G, Graell J, Lara I, López ML. Physicochemical measurements in 'Mondial Gala ${ }^{\circledR \prime}$ apples stored at different atmospheres: influence on consumer acceptability. Postharv Biol Technol. 2008;50:135-44. http://dx.doi.org/10.1016/j.postharvbio.2008.05.002

54. Villatoro C, Altisent R, Echeverría G, Graell J, López ML, Lara I. Changes in biosynthesis of aroma volatile compounds during on-tree maturation of 'Pink Lady ${ }^{\circledR \prime}$ apples. Postharv Biol Technol. 2008;47:286-95. http://dx.doi.org/10.1016/j.postharvbio.2007.07.003

55. Flath RA, Black DR, Forrey RR, McDonald GM, Mon TR, Teranishi R. Volatiles in Gravenstein apple essence identified by GC-mass spectrometry. J Chromatogr Sci. 1969;7:508-12. http://dx.doi.org/10.1093/chromsci/7.8.508

56. Takeoka GR, Flath RA, Mon TR, Teranishi R, Guentert M. Volatile constituents of apricot (Prunus armeniaca). J Agric Food Chem. 1990;38:471-7. http://dx.doi.org/10.1021/jf00092a031

57. Buttery RG, Seifert RM, Guadagni DG, Ling LC. Characterization of additional volatile components of tomato. J Agric Food Chem. 1971;19:524-9. http://dx.doi.org/10.1021/jf60175a011

58. Buttery RG, Turnbaugh JG, Ling LC. Contribution of volatiles to rice aroma. J Agric Food Chem. 1988;36:1006-9. http://dx.doi.org/10.1021/jf00083a025

59. Mehinagic E, Royer G, Symoneaux R, Jourjon F, Prost C. Characterization of odor-active volatiles in apples: influence of cultivars and maturity stage. J Agric Food Chem. 2006;54: 2678-87. http://dx.doi.org/10.1021/jf052288n

60. Takeoka G, Buttery RG, Ling L. Odour thresholds of various branched and straight chain acetates. LWT-Food Sci Technol. 1996;29:677-80. http://dx.doi.org/10.1006/fstl.1996.0105

61. Plotto A, McDaniel MR, Mattheis JP. Characterization of changes in 'Gala' apple aroma during storage using osme analysis, a gas chromatography-olfactometry technique. J Am Soc Hort Sci. 2000;125:714-22.

62. Rizzolo A, Visai C, Vanoli M. Changes in some odour-active compounds in paclobutrazol-treated 'Starkspur Golden' apples at harvest and after cold storage. Postharv Biol Technol. 1997;11:39-46. http://dx.doi.org/10.1016/S0925-5214(97)01417-8

63. Schwab W, Davidovich-Rikanati R, Lewinsohn E. Biosynthesis of plant-derived flavor compounds. Plant J. 2008;54:71232. http://dx.doi.org/10.1111/j.1365-313X.2008.03446.x

64. Osorio S, Muñoz C, Valpuesta V. Physiology and Biochemistry of fruit flavors. In: Hui YH, editor. Handbook of fruit and vegetable flavors. Hoboken, NJ, USA: John Wiley \& Sons, Inc; 2010. pp. 25-44. http://dx.doi.org/10.1002/9780470622834.ch2

65. Tressl R, Drawert F. Biogenesis of banana volatiles. J Agric Food Chem. 1973;21:560-5. http://dx.doi.org/10.1021/jf60188a031

66. Hansen K, Poll, L. Conversion of L-isoleucine into 2-methylbut-2-enyl esters in apples. LWT - Food Sci Technol. 1993;26: $178-80$. http://dx.doi.org/10.1021/jf60188a031

67. Matich A, Rowan D. Pathway analysis of branched-chain ester biosynthesis in apple using deuterium labeling and enantioselective gas chromatography-mass spectrometry. J Agric Food Chem. 2007;55:2727-35. http://dx.doi.org/10.1021/jf063018n
68. Sanz C, Pérez AG. Plant metabolic pathways and flavor biosynthesis. In: Hui $\mathrm{YH}$, editor. Handbook of fruit and vegetable flavors. Hoboken, NJ, USA: John Wiley \& Sons, Inc; 2010. pp. $129-55$. http://dx.doi.org/10.1002/9780470622834.ch9

69. Eisenreich W, Bacher A, Arigoni D, Rohdich F. Biosynthesis of isoprenoids via the non-mevalonate pathway. Cell Mol Life Sci. 2004;61:1401-26. http://dx.doi.org/10.1007/s00018-004-3381-z

70. Gang DR, Wang J, Dudareva N, Nam KH, Simon JE, Lewinsohn E, Pichersky E. An investigation of the storage and biosynthesis of phenylpropenes in sweet basil. Plant Physiol. 2001;125:539-55. http://dx.doi.org/10.1104/pp.125.2.539

71. Galliard T. Aspects of lipid metabolism in higher plants. II. The identification and quantitative analysis of lipids from the pulp of pre-and post-climacteric apples. Phytochemistry. 1968;7:1915-22. http://dx.doi.org/10.1016/S0031-9422(00)90751-9

72. Song J, Bangerth F. Fatty acids as precursors for aroma volatile biosynthesis in pre-climacteric and climacteric apple fruit. Postharv Biol Technol. 2003;30:113-21. http://dx.doi.org/10.1016/S0925-5214(03)00098-X

73. Meigh DF, Hulme AC. Fatty acid metabolism in the apple fruit during the respiration climacteric. Phytochemistry. 1965; 4:863-71. http://dx.doi.org/10.1016/S0031-9422(00)86264-0

74. Meigh DF, Jones JD, Hulme AC. The respiration climacteric in the apple: production of ethylene and fatty acids in fruit attached to and detached from the tree. Phytochemistry. 1967;6:1507-15. http://dx.doi.org/10.1016/S0031-9422(00)82943-X

75. Nie LC, Sun JS, Di B. Changes in amino acid and fatty acid contents as well as activity of some related enzymes in apple fruit during aroma production. Zhi wu sheng li yu fen zi sheng wu xue xue bao. 2005;31:663-7 (in Chinese).

76. Defilippi BG, Manríquez D, Luengwilai K, González-Agüero M. Aroma volatiles: biosynthesis and mechanisms of modulation during fruit ripening. In: Kader JC, Delseny M, editors. Advances in botanical research, vol. 50. Amsterdam, The Netherlands: Elsevier B.V.; 2009. pp. 1-37. http://dx.doi.org/10.1016/S0065-2296(08)00801-X

77. Tzin V, Galili G. New insights into the shikimate and aromatic amino acids biosynthesis pathways in plants. Mol Plant. 2010;3:956-72. http://dx.doi.org/10.1093/mp/ssq048

78. Ackermann J, Fischer M, Amado R. Changes in sugars, acids, and amino acids during ripening and storage of apples (cv. Glockenapfel). J Agric Food Chem. 1992;40:1131-44. http://dx.doi.org/10.1021/jf00019a008

79. Defilippi BG, Dandekar AM, Kader AA. Relationship of ethylene biosynthesis to volatile production, related enzymes, and precursor availability in apple peel and flesh tissues. J Agric Food Chem. 2005;53:3133-41. http://dx.doi.org/10.1021/jf047892x

80. Zhang Y, Li P, Cheng L. Developmental changes of carbohydrates, organic acids, amino acids, and phenolic compounds in 'Honeycrisp' apple flesh. Food Chem. 2010;123:1013-8. http://dx.doi.org/10.1016/j.foodchem.2010.05.053

81. Sugimoto $\mathrm{N}$, Jones $\mathrm{AD}$, Beaudry R. Changes in free amino acid content in 'Jonagold' apple fruit as related to branchedchain ester production, ripening, and senescence. J Am Soc Hort Sci. 2011;136:429-40.

82. Sanz LG, Pérez AG, Olías JM. Lipoxygenase in the plant kingdom. I: Properties. Grasas Aceites. 1992;43:231-9 (in Spanish).

http://dx.doi.org/10.3989/gya.1992.v43.i4.1157 
83. Bartley IM. Lipid metabolism of ripening apples. Phytochemistry. 1985;24:2857-9. http://dx.doi.org/10.1016/0031-9422(85)80014-5

84. Gardner HW. Biological roles and biochemistry of the lipoxygenase pathway. HortSci. 1995;30:197-205.

85. Park S, Sugimoto N, Larson MD, Beaudry R, van Nocker S. Identification of genes with potential roles in apple fruit development and biochemistry through large-scale statistical analysis of expressed sequence tags. Plant Physiol. 2006;141: $811-24$. http://dx.doi.org/10.1104/pp.106.080994

86. Goepfert S, Vidoudez C, Rezzonico E, Hiltunen JK, Poirier Y. Molecular identification and characterization of the Arabidopsis $\Delta^{3,5}, \Delta^{2,4}$-dienoyl-coenzyme A isomerase, a peroxisomal enzyme participating in the $\beta$-oxidation cycle of unsaturated fatty acids. Plant Physiol. 2005;138:1947-56. http://dx.doi.org/10.1104/pp.105.064311

87. Goepfert S, Poirier Y. $\beta$-Oxidation in fatty acid degradation and beyond. Curr Opin Plant Biol. 2007;10:245-51. http://dx.doi.org/10.1016/j.pbi.2007.04.007

88. Heldt HW, Piechulla B. Plant biochemistry. San Diego, CA, USA: Elsevier Inc; 2011.

89. Baker A, Graham IA, Holdsworth M, Smith SM, Theodoulou FL. Chewing the fat: $\beta$-oxidation in signalling and development. Trends Plant Sci. 2006;11:124-32. http://dx.doi.org/10.1016/j.tplants.2006.01.005

90. Graham IA, Eastmond PJ. Pathways of straight and branched chain fatty acid catabolism in higher plants. Prog Lipid Res. 2002;41:156-81. http://dx.doi.org/10.1016/S0163-7827(01)00022-4

91. Nelson D, Cox M. Lehninger principles of biochemistry. New York, NY, USA: W.H. Freeman \& Co; 2004.

92. Hamberg M, Samuelsson, B. On the specificity of the oxygenation of unsaturated fatty acids catalyzed by soybean lipoxidase. J Biol Chem. 1967;242:5329-35.

93. Holman RT, Egwim PO, Christie WW. Substrate specificity of soybean lipoxidase. J Biol Chem. 1969;244:1149-51.

94. Schneider C, Pratt DA, Porter NA, Brash AR. Control of oxygenation in lipoxygenase and cyclooxygenase catalysis. Chem Biol. 2007;14:473-88. http://dx.doi.org/10.1016/j.chembiol.2007.04.007

95. Feussner I, Wasternack C. The lipoxygenase pathway. Annu Rev Plant Biol. 2002;53:275-97. http://dx.doi.org/10.1146/annurev.arplant.53.100301.135248

96. Vogt J, Schiller D, Ulrich D, Schwab W, Dunemann F. Identification of lipoxygenase (LOX) genes putatively involved in fruit flavour formation in apple (Malus $\times$ domestica). Tree Genet Genomes. 2013;9:1493-511. http://dx.doi.org/10.1007/s11295-013-0653-5

97. Padilla MN, Hernández ML, Sanz C, Martínez-Rivas JM. Functional characterization of two 13-lipoxygenase genes from olive fruit in relation to the biosynthesis of volatile compounds of virgin olive oil. J Agric Food Chem. 2009;57: 9097-107. http://dx.doi.org/10.1021/jf901777j

98. Brash AR. Lipoxygenases: occurrence, functions, catalysis, and acquisition of substrate. J Biol Chem. 1999;274:23679-82. http://dx.doi.org/10.1074/jbc.274.34.23679

99. Liavonchanka A, Feussner I. Lipoxygenases: occurrence, functions and catalysis. J Plant Physiol. 2006;163:348-57. http://dx.doi.org/10.1016/j.jplph.2005.11.006

100. Porta H, Rocha-Sosa M. Plant lipoxygenases. Physiological and molecular features. Plant Physiol. 2002;130:15-21. http://dx.doi.org/10.1104/pp.010787

101. Palmieri-Thiers C, Canaan S, Brunini V, Lorenzi V, Tomi F, Desseyn JL, et al. A lipoxygenase with dual positional speci- ficity is expressed in olives (Olea europaea L.) during ripening. BBA - Mol Cell Biol. 2009;1791:339-46. http://dx.doi.org/10.1016/j.bbalip.2009.02.012

102. Cho K, Han J, Rakwal R, Han O. Calcium modulates membrane association, positional specificity, and product distribution in dual positional specific maize lipoxygenase-1. Bioorg Chem. 2015;60:13-8. http://dx.doi.org/10.1016/j.bioorg.2015.04.001

103. Li M, Li L, Dunwell JM, Qiao X, Liu X, Zhang S. Characterization of the lipoxygenase (LOX) gene family in the Chinese white pear (Pyrus bretschneideri) and comparison with other members of the Rosaceae. BMC Genomics. 2014;15:444. http://dx.doi.org/10.1186/1471-2164-15-444

104. The Pfam protein families database. Ashburn, VA, USA: Janelia Research Campus. 2015. Available from: https://pfam. janelia.org/.

105. Velasco R, Zharkikh A, Affourtit J, Dhingra A, Cestaro A, Kalyanaraman A, et al. The genome of the domesticated apple (Malus domestica Borkh.). Nat Genet. 2010;42:833-9. http://dx.doi.org/10.1038/ng.654

106. Schiller D, Contreras C, Vogt J, Dunemann F, Defilippi BG, Beaudry R, Schwab W. A dual positional specific lipoxygenase functions in the generation of flavor compounds during climacteric ripening of apple. Hortic Res. 2015;2:Article no. 15003. http://dx.doi.org/10.1038/hortres.2015.3

107. Contreras $\mathrm{C}$. The lipoxygenase pathway in apple peel $[\mathrm{PhD}$ Thesis]. East Lansing, MI, USA: Michigan State University; 2014.

108. Feussner I, Kühn H, Wasternack C. Lipoxygenase-dependent degradation of storage lipids. Trends Plant Sci. 2001;6: 268-73. http://dx.doi.org/10.1016/S1360-1385(01)01950-1

109. Schreier P, Lorenz G. Separation, partial purification and characterization of a fatty acid hydroperoxide cleaving enzyme from apple and tomato fruits. Z Naturforsch C Bio Sci. 1982;37:165-73. http://dx.doi.org/10.1515/znc-1982-3-405

110. Sanz LC, Perez AG, Olias JM. Lipoxygenase in the plant kingdom. II: Physiological functions assigned. Grasas Aceites. 1992;43:287-90 (in Spanish). http://dx.doi.org/10.3989/gya.1992.v43.i5.1143

111. Vick BA. A spectrophotometric assay for hydroperoxide lyase. Lipids. 1991;26:315-20. http://dx.doi.org/10.1007/BF02537143

112. Li X, Guo R, Li J, Singer SD, Zhang Y, Yin X, et al. Genome-wide identification and analysis of the aldehyde dehydrogenase $(\mathrm{ALDH})$ gene superfamily in apple (Malus $\times$ domestica Borkh.). Plant Physiol Biochem. 2013;71:268-82. http://dx.doi.org/10.1016/j.plaphy.2013.07.017

113. Bicsak TA, Kann LR, Reiter A, Chase Jr. T. Tomato alcohol dehydrogenase: purification and substrate specificity. Arch Biochem Biophys. 1982;216:605-15. http://dx.doi.org/10.1016/0003-9861(82)90250-8

114. Crouzet J, Nicolas M, Molina I, Valentin G. Enzymes occurring in the formation of six-carbon aldehydes and alcohols in grapes. Dev Food Sci. 1985;10:401-8.

115. Dixon J, Hewett EW. Factors affecting apple aroma/flavour volatile concentration: a review. New Zeal J Crop Hort. 2000; 28:155-73. http://dx.doi.org/10.1080/01140671.2000.9514136

116. Hummel W. New alcohol dehydrogenases for the synthesis of chiral compounds. In: Scheper T, editor. Advances in biochemical engineering/biotechnology, vol. 58: New enzymes for organic synthesis. Berlin, Germany: Springer-Verlag; 1997. pp. $145-84$.

http://dx.doi.org/10.1007/BFb0103304 
117. Dixon J, Hewett EW. Temperature of hypoxic treatment alters volatile composition of juice from 'Fuji'and 'Royal Gala' apples. Postharv Biol Technol. 2001;22:71-83. http://dx.doi.org/10.1016/S0925-5214(00)00159-9

118. Souleyre EJF, Chagné D, Chen X, Tomes S, Turner RM, Wang MY, et al. The AAT1 locus is critical for the biosynthesis of esters contributing to 'ripe apple' flavour in 'Royal Gala' and 'Granny Smith' apples. Plant J. 2014;78:903-15. http://dx.doi.org/10.1111/tpj.12518

119. Ortiz A, Graell J, Lara I. Volatile ester-synthesising capacity throughout on-tree maturation of 'Golden Reinders' apples. Sci Hortic. 2011;131:6-14. http://dx.doi.org/10.1016/j.scienta.2011.09.020

120. Contreras C, Beaudry R. Lipoxygenase-associated apple volatiles and their relationship with aroma perception during ripening. Postharv Biol Technol. 2013;82:28-38. http://dx.doi.org/10.1016/j.postharvbio.2013.02.006

121. Yang X, Song J, Du L, Forney C, Campbell-Palmer L, Fillmore $\mathrm{S}$, et al. Ethylene and 1-MCP regulate major volatile biosynthetic pathways in apple fruit. Food Chem. 2016;194:325-36. http://dx.doi.org/10.1016/j.foodchem.2015.08.018

122. Feys M, Naesens W, Tobback P, Maes E. Lipoxygenase activity in apples in relation to storage and physiological disorders. Phytochemistry. 1980;19:1009-11. http://dx.doi.org/10.1016/0031-9422(80)83048-2

123. Lara I, Graell J, López ML, Echeverría G. Multivariate analysis of modifications in biosynthesis of volatile compounds after CA storage of 'Fuji' apples. Postharv Biol Technol. 2006; 39:19-28. http://dx.doi.org/10.1016/j.postharvbio.2005.09.001

124. Lara I, Echeverría G, Graell J, López ML. Volatile emission after controlled atmosphere storage of Mondial Gala apples (Malus domestica): relationship to some involved enzyme activities. J Agric Food Chem. 2007;55:6087-95. http://dx.doi.org/10.1021/jf070464h

125. Altisent R, Echeverría G, Graell J, López L, Lara I. Lipoxygenase activity is involved in the regeneration of volatile ester-synthesizing capacity after ultra-low oxygen storage of 'Fuji' apple. J Agric Food Chem. 2009;57:4305-12. http://dx.doi.org/10.1021/jf803930j

126. Harb J, Lara I, Streif J, Saleh O, Khraiwesh B. Ethylene suppression modifies gene expression and activity of aroma volatile-related enzymes in 'Delbard Estivale' apples. Acta Hortic. 2010;877:1093-8. http://dx.doi.org/10.17660/ActaHortic.2010.877.148

127. Li D, Xu Y, Xu G, Gu L, Li D, Shu H. Molecular cloning and expression of a gene encoding alcohol acyltransferase (MdAAT2) from apple (cv. Golden Delicious). Phytochemistry. 2006;67:658-67.

http://dx.doi.org/10.1016/j.phytochem.2006.01.027

128. Villatoro C, Echeverría G, Graell J, López ML, Lara I. Long-term storage of Pink Lady apples modifies volatile-involved enzyme activities: consequences on production of volatile esters. J Agric Food Chem. 2008;56:9166-74. http://dx.doi.org/10.1021/jf801098b

129. López ML, Villatoro C, Fuentes T, Graell J, Lara I, Echeverría G. Volatile compounds, quality parameters and consumer acceptance of 'Pink Lady ${ }^{\circledR \prime}$ apples stored in different conditions. Postharv Biol Technol. 2007;43:55-66. http://dx.doi.org/10.1016/j.postharvbio.2006.07.009

130. Li DP, Xu YF, Sun LP, Liu LX, Hu XL, Li DQ, Shu HR. Salicylic acid, ethephon, and methyl jasmonate enhance ester regeneration in 1-MCP-treated apple fruit after long-term cold storage. J Agric Food Chem. 2006;54:3887-95. http://dx.doi.org/10.1021/jf060240j

131. Zhao Y, Zhang L, Gao M, Tian L, Zheng P, Wang K, et al. Influence of girdling and foliar-applied urea on apple (Malus domestica L.) fruit quality. Pak J Bot. 2013;45:1609-15.
132. Ban Y, Oyama-Okubo N, Honda C, Nakayama M, Moriguchi T. Emitted and endogenous volatiles in 'Tsugaru' apple: the mechanism of ester and (E,E)- $\alpha$-farnesene accumulation. Food Chem. 2010;118:272-7. http://dx.doi.org/10.1016/j.foodchem.2009.04.109

133. Zhu Y, Rudell DR, Mattheis JP. Characterization of cultivar differences in alcohol acyltransferase and 1-aminocyclopropane-1-carboxylate synthase gene expression and volatile ester emission during apple fruit maturation and ripening. Postharv Biol Technol. 2008;49:330-9. http://dx.doi.org/10.1016/j.postharvbio.2008.03.015

134. Ortiz A, Echeverría G, Graell J, Lara I. Calcium dips enhance volatile emission of cold-stored 'Fuji Kiku-8' apples. J Agric Food Chem. 2009;57:4931-8. http://dx.doi.org/10.1021/jf9003576

135. Escalada VS, Archbold DD. Effects of aminoethoxyvinylglycine plus 1-methylcyclopropene on 'Royal Gala' apple volatile production after cold storage. HortSci. 2009;44:1390-4.

136. Ortiz A, Echeverría G, Graell J, Lara I. The emission of flavour-contributing volatile esters by 'Golden Reinders' apples is improved after mid-term storage by postharvest calcium treatment. Postharv Biol Technol. 2010;57:114-23. http://dx.doi.org/10.1016/j.postharvbio.2010.03.006

137. Rowan DD, Allen JM, Fielder S, Hunt MB. Deuterium labelling to study aroma biosynthesis in stored apples. In: Mitchman EJ, editor. Postharvest Horticulture Series, vol. 16. Davis, CA, USA: University of California; 1997. pp. 227-33.

138. Diebold R, Schuster J, Däschner K, Binder S. The branchedchain amino acid transaminase gene family in Arabidopsis encodes plastid and mitochondrial proteins. Plant Physiol. 2002. pp. 540-50. http://dx.doi.org/10.1104/pp.001602

139. Schuster J, Binder S. The mitochondrial branched-chain aminotransferase (AtBCAT-1) is capable to initiate degradation of leucine, isoleucine and valine in almost all tissues in Arabidopsis thaliana. Plant Mol Biol. 2005;57:241-54. http://dx.doi.org/10.1007/s11103-004-7533-1

140. Smit BA, Engels WJ, Smit G. Branched chain aldehydes: production and breakdown pathways and relevance for flavour in foods. Appl Microbiol Biotechnol. 2009;81:987-99. http://dx.doi.org/10.1007/s00253-008-1758-x

141. Binder S. Branched-chain amino acid metabolism in Arabidopsis thaliana. The Arabidopsis book. 2010;8:e137. http://dx.doi.org/10.1199/tab.0137

142. Marilley L, Casey MG. Flavours of cheese products: metabolic pathways, analytical tools and identification of producing strains. Int J Food Microbiol. 2004;90:139-59. http://dx.doi.org/10.1016/S0168-1605(03)00304-0

143. Dickinson JR, Harrison SJ, Dickinson JA, Hewlins MJE. An investigation of the metabolism of isoleucine to active amyl alcohol in Saccharomyces cerevisiae. J Biol Chem. 2000;275: 10937-42. http://dx.doi.org/10.1074/jbc.275.15.10937

144. Dickinson JR, Salgado LEJ, Hewlins MJE. The catabolism of amino acids to long chain and complex alcohols in Saccharomyces cerevisiae. J Biol Chem. 2003;278:8028-34. http://dx.doi.org/10.1074/jbc.M211914200

145. Ardö Y. Flavour formation by amino acid catabolism. Biotechnol Adv. 2006;24:238-42. http://dx.doi.org/10.1016/j.biotechadv.2005.11.005

146. Schuster J, Knill T, Reichelt M, Gershenzon J, Binder S. Branched-chain aminotransferase ${ }_{4}$ is part of the chain elongation pathway in the biosynthesis of methionine-derived glucosinolates in Arabidopsis. The Plant Cell. 2006;18:266479 . http://dx.doi.org/10.1105/tpc.105.039339 
147. Dickinson JR, Harrison SJ, Hewlins MJE. An investigation of the metabolism of valine to isobutyl alcohol in Saccharomyces cerevisiae. J Biol Chem. 1998;273:25751-6. http://dx.doi.org/10.1074/jbc.273.40.25751

148. Ehrlich F. Conditions for fusel oil formation and its connection with the protein formation in yeast. Ber Dtsch Chem Ges. 1907;40:1027-47 (in German). http://dx.doi.org/10.1002/cber.190704001156

149. Brosnan JT, Brosnan ME. Branched-chain amino acids: enzyme and substrate regulation. J Nutr. 2006;136:207S-11S.

150. Hiltunen JK, Mursula AM, Rottensteiner H, Wierenga RK, Kastaniotis AJ, Gurvitz A. The biochemistry of peroxisomal $\beta$-oxidation in the yeast Saccharomyces cerevisiae. FEMS Microbiol Rev. 2003;27:35-64. http://dx.doi.org/10.1016/S0168-6445(03)00017-2

151. Ikeda Y, Tanaka K. Purification and characterization of 2-methyl-branched chain acyl coenzyme A dehydrogenase, an enzyme involved in the isoleucine and valine metabolism, from rat liver mitochondria. J Biol Chem. 1983;258:947787.

152. Eisenreich W, Rohdich F, Bacher A. Deoxyxylulose phosphate pathway to terpenoids. Trends Plant Sci. 2001;6:78-84. http://dx.doi.org/10.1016/S1360-1385(00)01812-4

153. El Hadi MAM, Zhang FJ, Wu FF, Zhou CH, Tao J. Advances in fruit aroma volatile research. Molecules. 2013;18:8200-29. http://dx.doi.org/10.3390/molecules18078200

154. Nieuwenhuizen NJ, Green SA, Chen X, Bailleul EJD, Matich AJ, Wang MY, Atkinson RG. Functional genomics reveals that a compact terpene synthase gene family can account for terpene volatile production in apple. Plant Physiol. 2013;161: 787-804.

http://dx.doi.org/10.1104/pp.112.208249

155. Rupasinghe HPV, Paliyath G, Murr DP. Biosynthesis of $\alpha$-farnesene and its relation to superficial scald development in 'Delicious' apples. J Am Soc Hort Sci. 1998;123:882-6.

156. Ju Z, Curry EA. Evidence that $\alpha$-farnesene biosynthesis during fruit ripening is mediated by ethylene regulated gene expression in apples. Postharv Biol Technol. 2000;19:9-16. http://dx.doi.org/10.1016/S0925-5214(00)00078-8

157. Whitaker BD. Oxidative stress and superficial scald of apple fruit. HortSci. 2004;39:933-7.

158. Pechous SW, Whitaker BD. Cloning and functional expression of an (E,E)- $\alpha$-farnesene synthase cDNA from peel tissue of apple fruit. Planta. 2004;219:84-94.

159. Fraternale D, Ricci D, Flamini G, Giomaro G. Volatile profile of red apple from Marche region (Italy). Rec Nat Prod. 2011; 5:202-7.

160. Rapparini F, Baraldi R, Facini O. Seasonal variation of monoterpene emission from Malus domestica and Prunus avium. Phytochemistry. 2001;57:681-7.

http://dx.doi.org/10.1016/S0031-9422(01)00124-8

161. Ferreira L, Perestrelo R, Caldeira M, Câmara JS. Characterization of volatile substances in apples from Rosaceae family by headspace solid-phase microextraction followed by GC-qMS. J Sep Sci. 2009;32:1875-88. http://dx.doi.org/10.1002/jssc.200900024

162. Yauk YK, Chagné D, Tomes S, Matich AJ, Wang MY, Chen $X$, et al. The O-methyltransferase gene MdoOMT1 is required for biosynthesis of methylated phenylpropenes in ripe apple fruit. Plant J. 2015;82:937-50. http://dx.doi.org/10.1111/tpj.12861

163. Song J, Bangerth F. The effect of harvest date on aroma compound production from 'Golden Delicious' apple fruit and relationship to respiration and ethylene production. Postharv Biol Technol. 1996;8:259-69.

http://dx.doi.org/10.1016/0925-5214(96)00020-8
164. Salas NA, Molina-Corral FJ, Gonzalez-Aguilar GA, Otero A, Sepulveda DR, Olivas GI. Volatile production by 'Golden Delicious' apples is affected by preharvest application of aminoethoxyvinylglycine. Sci Hortic. 2011;130:436-44. http://dx.doi.org/10.1016/j.scienta.2011.07.017

165. Young H, Gilbert JM, Murray SH, Ball RD. Causal effects of aroma compounds on Royal Gala apple flavours. J Sci Food Agric. 1996;71:329-36.

http://dx.doi.org/10.1002/(SICI)1097-0010(199607)71:3<329: :AID-JSFA588>3.0.CO;2-8

166. Fellman J, Mattison D, Fan X, Mattheis J. 'Fuji' apple storage characteristics in relation to growing conditions and harvest maturity in Washington State. Proceedings of 7th International Controlled Atmosphere Research Conference, vol. 2; 1997 July 13-18; Davis, CA, USA: University of California; 1997. p. 234.

167. Rizzolo A, Visai C. Studies on the quality of 'Golden Delicious' apples coming from different localities of Trentino. Proceedings of 23rd International Horticultural Congress; 1990 August 30; Florence, Italy. Wagenigen, The Netherlands: ISHS; 1992.

168. Forsyth FR, Webster DH. Volatiles from McIntosh apple fruits as affected by phosphorus and potassium nutrition. J Am Soc Hortic Sci. 1971;96:259-63.

169. Echeverría G, Graell J, López ML. Effect of harvest date and storage conditions on quality and aroma production of 'Fuji' apples. Food Sci Technol Int. 2002;8:351-60. http://dx.doi.org/10.1106/1082013202031478

170. Kalua CM, Allen MS, Bedgood Jr. DR, Bishop AG, Prenzler PD, Robards K. Olive oil volatile compounds, flavour development and quality: a critical review. Food Chem. 2007;100: 273-86. http://dx.doi.org/10.1016/j.foodchem.2005.09.059

171. Lay-Yee M, DellaPenna D, Ross GS. Changes in mRNA and protein during ripening in apple fruit (Malus domestica Borkh. cv Golden Delicious). Plant Physiol. 1990;94:850-3. http://dx.doi.org/10.1104/pp.94.2.850

172. Defilippi BG, Dandekar AM, Kader AA. Impact of suppression of ethylene action or biosynthesis on flavor metabolites in apple (Malus domestica Borkh) fruits. J Agric Food Chem. 2004;52:5694-701. http://dx.doi.org/10.1021/jf049504x

173. Kondo S, Setha S, Rudell DR, Buchanan DA, Mattheis JP. Aroma volatile biosynthesis in apples affected by $1-\mathrm{MCP}$ and methyl jasmonate. Postharv Biol Technol. 2005;36:61-8. http://dx.doi.org/10.1016/j.postharvbio.2004.11.005

174. Bai J, Baldwin EA, Goodner KL, Mattheis JP, Brecht JK. Response of four apple cultivars to 1-methylcyclopropene treatment and controlled atmosphere storage. HortSci. 2005;40: 1534-8.

175. Marin AB, Colonna AE, Kudo K, Kupferman EM, Mattheis JP. Measuring consumer response to 'Gala' apples treated with 1-methylcyclopropene (1-MCP). Postharv Biol Technol. 2009;51:73-9. http://dx.doi.org/10.1016/j.postharvbio.2008.06.008

176. Lurie S, Pre-Aymard C, Ravid U, Larkov O, Fallik E. Effect of 1-methylcyclopropene on volatile emission and aroma in cv. Anna apples. J Agric Food Chem. 2002;50:4251-6. http://dx.doi.org/10.1021/jf0200873

177. Halder-Doll H, Bangerth F. Inhibition of auto catalytic $\mathrm{C}_{2} \mathrm{H}_{4}$ biosynthesis by AVG applications and consequences on the physiological behaviour and quality of apple fruits in cool storage. Sci Hortic. 1987;33:87-96. http://dx.doi.org/10.1016/0304-4238(87)90035-5

178. Fan X, Mattheis JP, Buchanan D. Continuous requirement of ethylene for apple fruit volatile synthesis. J Agric Food Chem. 1998;46:1959-63.

http://dx.doi.org/10.1021/jf970877q 
179. Harb J, Streif J, Bangerth F. Response of controlled atmosphere (CA) stored 'Golden Delicious' apples to the treatments with alcohols and aldehydes as aroma precursors. Gartenbauwissenschaft. 2000;65:154-61.

180. Mattheis JP, Fellman JK. Preharvest factors influencing flavor of fresh fruit and vegetables. Postharv Biol Technol. 1999;15: $227-32$. http://dx.doi.org/10.1016/S0925-5214(98)00087-8

181. Bachmann U. Volatile compounds in apples dependent on harvesting date and after-ripening conditions. Acta Hortic. 1982;77-82.

http://dx.doi.org/10.17660/ActaHortic.1983.138.8

182. Brown DS, Buchanan JR, Hicks JR. Volatiles from apples as related to variety, maturity, and storage. Hilgardia. 1968;39: 37-67.

http://dx.doi.org/10.3733/hilg.v39n02p037

183. Song J, Bangerth F. Production and development of volatile aroma compounds of apple fruits at different times of maturity. Acta Hortic. 1993;368:150-9. http://dx.doi.org/10.17660/ActaHortic.1994.368.16

184. Brackmann A, Streif J, Bangerth F. Relationship between a reduced aroma production and lipid metabolism of apples after long-term controlled-atmosphere storage. J Am Soc Hort Sci. 1993;118:243-7.

185. Hansen K, Poll L, Olsen CE, Lewis MJ. The influence of oxygen concentration in storage atmospheres on the post-storage volatile ester production of Jonagold apples. LWT Food Sci Technol. 1992;25:457-61.

186. Young JC, Chu CLG, Lu X, Zhu H. Ester variability in apple varieties as determined by solid-phase microextraction and gas chromatography-mass spectrometry. J Agric Food Chem. 2004;52:8086-93.

http://dx.doi.org/10.1021/jf049364r

187. Argenta LC, Mattheis JP, Fan X, Finger FL. Production of volatile compounds by Fuji apples following exposure to high $\mathrm{CO}_{2}$ or low $\mathrm{O}_{2}$. J Agric Food Chem. 2004;52:5957-63. http://dx.doi.org/10.1021/jf049495s

188. Streif J, Bangerth F. Production of volatile aroma substances by 'Golden Delicious' apple fruits after storage for various times in different $\mathrm{CO}_{2}$ and $\mathrm{O}_{2}$ concentrations. J Hortic Sci. 1988;63:193-9.
189. Harwood JL. Fatty acid metabolism. An Rev Plant Physiol Mol Biol. 1988;39:101-38. http://dx.doi.org/10.1146/annurev.pp.39.060188.000533

190. Saquet AA, Streif J, Bangerth F. Impaired aroma production of CA-stored 'Jonagold' apples as affected by adenine and pyridine nucleotide levels and fatty acid concentrations. J Hortic Sci Biotech. 2003;78:695-705. http://dx.doi.org/10.1080/14620316.2003.11511686

191. Williams AA, Knee M. The flavour of Cox's Orange Pippin apples and its variation with storage. Ann Appl Biol. 1977;87: 127-31. http://dx.doi.org/10.1111/j.1744-7348.1977.tb00670.x

192. Berger RG, Drawert F. Changes in the composition of volatiles by post-harvest application of alcohols to red delicious apples. J Sci Food Agr. 1984;35:1318-25. http://dx.doi.org/10.1002/jsfa.2740351208

193. Maya-Meraz IO, Espino-Díaz M, Molina-Corral FJ, González-Aguilar GA, Jacobo-Cuellar JL, Sepulveda DR, Olivas GI. Production of volatiles in fresh-cut apple: effect of applying alginate coatings containing linoleic acid or isoleucine. J Food Sci. 2014;79:C2185-91. http://dx.doi.org/10.1111/1750-3841.12657

194. Dixon J. Enhancement of aroma and flavour volatiles in apple juice $[\mathrm{PhD}$ Thesis]. Palmerston North, New Zeland: Massey University; 1999.

195. De Pooter HL, Montens JP, Willaert GA, Dirinck PJ, Schamp NM. Treatment of Golden Delicious apples with aldehydes and carboxylic acids: effect on the headspace composition. J Agric Food Chem. 1983;31:813-8. http://dx.doi.org/10.1021/jf00118a034

196. Ferenczi A, Song J, Tian M, Vlachonasios K, Dilley D, Beaudry R. Volatile ester suppression and recovery following 1-methylcyclopropene application to apple fruit. J Am Soc Hortic Sci. 2006;131:691-701.

197. Rudell DR, Mattinson DS, Mattheis JP, Wyllie SG, Fellman JK. Investigations of aroma volatile biosynthesis under anoxic conditions and in different tissues of 'Redchief Delicious' apple fruit (Malus domestica Borkh.). J Agric Food Chem. 2002;50:2627-32. http://dx.doi.org/10.1021/jf011152w

198. Wyllie SG, Fellman JK. Formation of volatile branched chain esters in bananas (Musa sapientum L.). J Agric Food Chem. 2000;48:3493-6. http://dx.doi.org/10.1021/jf0001841 